\title{
Market development and consequences on end-of-life management of photovoltaic implementation in Europe
}

\author{
Manuela Franz ${ }^{1 *}$ and Gerhard Piringer ${ }^{2}$
}

\begin{abstract}
Background: The 2018 European Renewables Directive sets a binding target of 32\% of renewable energy generation by 2030. Free-field photovoltaic plants are characterised by significant land use and material flows. Although country-level data on installed power is available, information about the spatial distribution of PV plants is rare. When the first photovoltaic systems will reach their end-of-life on a large scale in 2035, economic, technological and ecological challenges will arise.

Methods: The study explores the market development of photovoltaic power in the EU countries from 2008 to 2017 by preparing statistical data and Google mapping of free-field PV plants. Different approaches to assessing the land use of free-field PV systems compared to other energy systems are investigated. A comprehensive literature review addresses key issues of PV module waste treatment, hazardous constituents and their leakage in case of module breakage as well as financial issues of decommissioning and recycling and re-use of used modules.

Results: Most of the European PV electrical energy is generated by approximately 17,000 widely distributed freefield plants predominantly installed in lowlands. A local in-depth study shows that roof-top plants contribute less than 5\% to the total PV energy generation in an area without extensive expansion to industrial buildings. Small amounts of hazardous substances that are typically present in PV modules are unlikely to affect the environment during normal operation of the system, but the question of leakage from broken end-of-life modules is not sufficiently clarified. While in the EU, the recycling and disposal costs are covered by producer fees and expected raw material profits; the financing of the decommissioning of thousands of PV free-field plants is still an open issue.

Conclusions: The land use of free-field PV systems should be analysed in more detail. Concerning hazardous substances, there seems to be an emerging consensus in literature that the leaching behaviour of metals from broken PV module pieces is inadequately simulated by current waste characterisation protocols. It is recommended to pay greater attention to financing the decommissioning of free-field commercial and industrial scale PV systems.
\end{abstract}

Keywords: Photovoltaic, PV, Market, Free-field, Ground-based, Renewable energy, Europe, E-waste, Leakage, Decommissioning, End-of-life

\footnotetext{
* Correspondence: manuela.franz@tuwien.ac.at

${ }^{1}$ TU-Wien, Gußhausstraße 27-29/E366, 1040 Wien, Austria

Full list of author information is available at the end of the article
}

(C) The Author(s). 2020 Open Access This article is licensed under a Creative Commons Attribution 4.0 International License, which permits use, sharing, adaptation, distribution and reproduction in any medium or format, as long as you give appropriate credit to the original author(s) and the source, provide a link to the Creative Commons licence, and indicate if changes were made. The images or other third party material in this article are included in the article's Creative Commons licence, unless indicated otherwise in a credit line to the material. If material is not included in the article's Creative Commons licence and your intended use is not permitted by statutory regulation or exceeds the permitted use, you will need to obtain permission directly from the copyright holder. To view a copy of this licence, visit http://creativecommons.org/licenses/by/4.0/ The Creative Commons Public Domain Dedication waiver (http://creativecommons.org/publicdomain/zero/1.0/) applies to the data made available in this article, unless otherwise stated in a credit line to the data. 


\section{Background}

The European 2009 Renewables Directive [1] obliges member states to reach together a share of $20 \%$ of energy from renewable sources by 2020. In 2018, a recast of the Renewables Directive was published by the European Commission, which foresees a binding target of $32 \%$ of renewable energy sources by 2030 . Austria has a mandatory renewable energy target of $34 \%$ of the national gross final energy consumption by 2020 [2].

Besides wind energy, hydropower, and geothermal energy, free-field PV energy systems are based on a high level of direct land consumption during the energy generation stage, which characterises the renewable energy market. The land occupation of free-field PV systems in Western Styria, Austria, is $0.0192 \mathrm{~m}^{2} \mathrm{a} / \mathrm{kWh}$ [3]. A further significant part of land consumption as energy resource is caused by biomass in terms of the cultivation of corn for biogas, rapeseed for biofuel, or poplars in short-rotation forestry for block heat and power stations. The land occupation for biomass is in the range of 0.3 $\mathrm{m}^{2} \mathrm{a} / \mathrm{kWh}[3,4]$. An earlier study compared the direct land use of renewable and fossil energy systems. Biogas shows a land transformation of $0.0125 \mathrm{~m}^{2} / \mathrm{kWh}$, hydroelectric reservoir $0.0041 \mathrm{~m}^{2} / \mathrm{kWh}$, photovoltaic in Germany $0.0007 \mathrm{~m}^{2} / \mathrm{kWh}$, and coal between $0.00014 \mathrm{~m}^{2} /$ $\mathrm{kWh}$ and $0.00089 \mathrm{~m}^{2} / \mathrm{kWh}$ [5]. The calculation method of the latter study underestimates the problem of land consumption.

Since the EU Renewables Directive entered into force, a considerable number of free-field PV solar parks using different technologies, scales and locations were built all over Europe over the last years. According to the current Photovoltaic Barometer [6], in total, 106.6 $\mathrm{GW}_{\mathrm{p}}$ photovoltaic power was installed, and $114 \mathrm{TWh}$ photovoltaic electrical energy was generated in the EU28 in 2017. The Fraunhofer Institute determined the cumulated photovoltaic power in Europe at $115 \mathrm{GW}_{\mathrm{p}}$ at the end of 2017 [7].

The reported country-specific cumulative installed power of [6] does not distinguish between roof-top plants, facade integrated plants and free-field plants. The European Global Market Outlook for Solar Power provides country data of the distribution of residential, commercial, industrial and utility scale PV plants. Residential scale is defined with an installed power $\leq 10$ $\mathrm{kW}_{\mathrm{p}}$, commercial scale between 10 and $250 \mathrm{~kW}_{\mathrm{p}}$, industrial scale $>250 \mathrm{~kW}_{\mathrm{p}}$ and utility scale $>1 \mathrm{MW}_{\mathrm{p}}$. Residential scale represents roof-top plants, and utility scale is defined as built on the ground. Commercial and industrial scales are not defined, and they can represent in practice both roof-top and free-field plants. In 2018, the share of the cumulative installed power of selected countries is indicated as follows: Germany, utility scale $27 \%$ and industrial scale 14\%; Italy, utility scale $20 \%$ and industrial scale $40 \%$; the UK, utility scale $63 \%$ and industrial scale 5\%; Spain, utility scale $81 \%$ and industrial scale $7 \%$; and Greece, utility scale $27 \%$ and industrial scale $23 \%$. Belgium has a share of residential cumulative installed power of $62 \%$. On the basis of the provided data, 5 to $95 \%$ of the respective country-specific cumulative installed power cannot be assigned with certainty to roof-top or free-field plants $[8,9]$.

In about 15 years, that is 2035 , the first large-scale generation of PV modules throughout Europe will reach its end of life. Since 2012, the waste management of PV modules is covered by the recast of the European WEEE-Directive [10], which regulates the waste management and treatment of electrical and electronic products. In 2016, 12.3 million tonnes electronic waste (ewaste) was generated in Europe including Russia. Thereof, only $35 \%$ were documented to be collected and recycled [11]. The predicted lifetime of PV modules is more than 25 years. In 2050, a total amount of 9.5 million tonnes end-of-life PV modules is expected in Europe [12]. Best practice treatment and recycling of photovoltaic panels including heavy metals are still under development, and an economically viable waste management of all PV module technologies cannot yet be assessed.

Besides recovery and recycling of the collected modules, the deconstruction and collection logistics and their financial efforts for small-scale roof-top plants with 5 $\mathrm{kW}_{\mathrm{p}}$ or large-scale solar fields with $100 \mathrm{MW}_{\mathrm{p}}$ are very different. There is no clear information about the numerical balance between PV modules in urban areas and modules installed in free-field plants. Figures 1, 2 and 3 show examples of small, medium, and large scale freefield PV plants in different European regions.

The aim of this work is to investigate the amount, location, scale, and distribution of free-field PV plants in Europe by statistical data analysis and Google mapping to get an overview on the current environmental and future end-of-life situation. Furthermore, the relation between roof-top plants and free-field plants is investigated by a local detailed analysis in South Moravia, Czech Republic. The region is chosen as it has a representative size, an effective PV expansion, and the satellite images of the entire area were of the same actual date with high image resolution.

The evaluation of land use and land occupation is generally carried out using standardised life cycle assessment methods $[15,16]$. The study examines the extent to which conservative calculations and methodical approaches for determination of the land consumption reflect the current land competition of renewable energy systems.

There are economic, technological, ecological and logistical challenges to be met when the first photovoltaic systems reach their end-of-life on a large scale in 2035. The study reviews and discusses the state of knowledge 


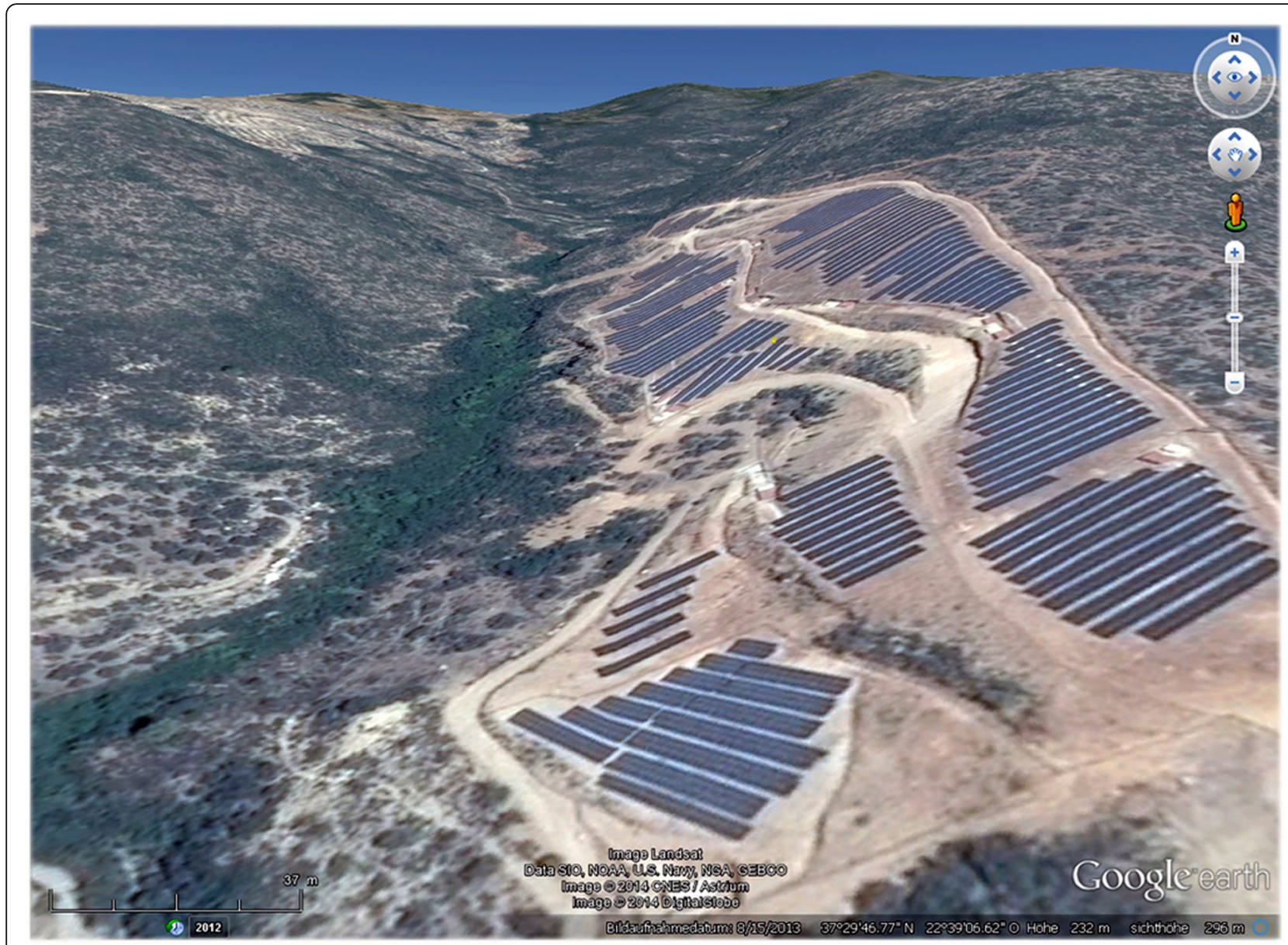

Fig. 1 Free-field photovoltaic plant with an installed power of $3 \mathrm{MW}_{\mathrm{p}}$ in the mountains near Velanidia, Peloponnese region, Greece (Google Earth, 2019 [13], image recording data: 26 October 2013)

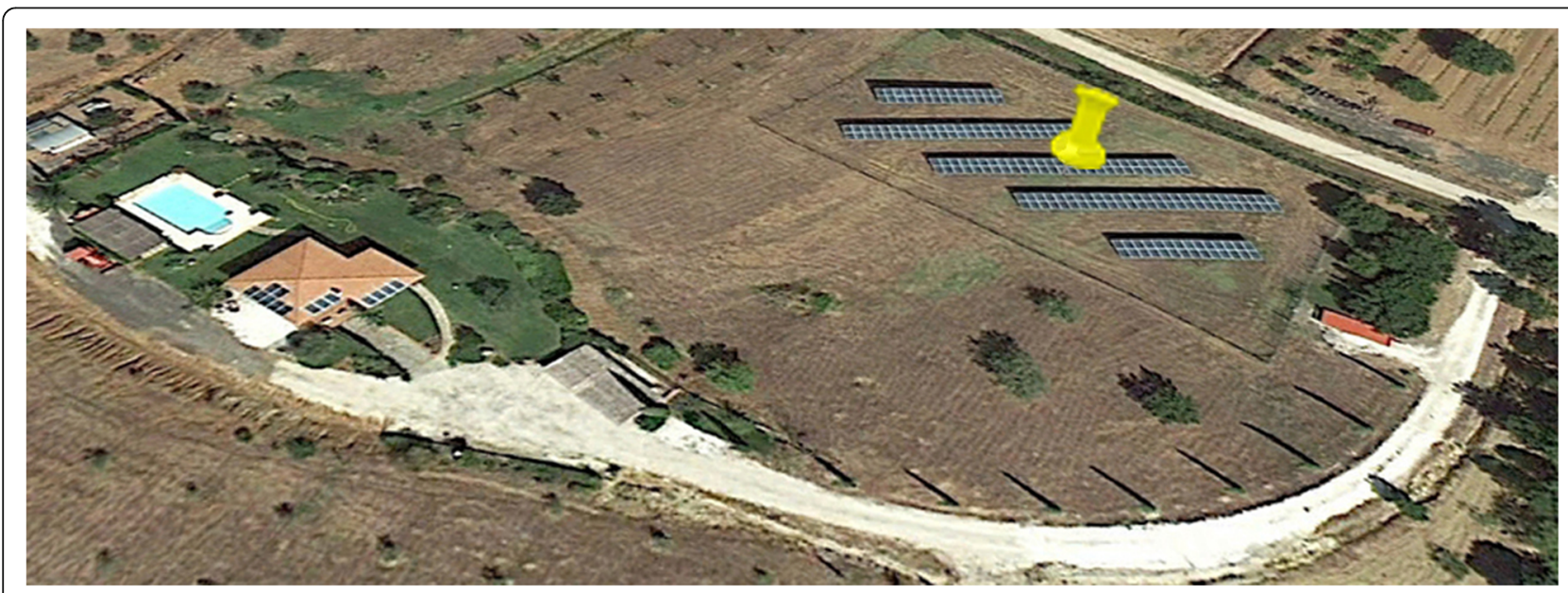

Fig. 2 Small free-field and roof-top plant in the Tuscany region, Italy (Google Earth, 2019 [13], image recording data: 8 December 2013) 


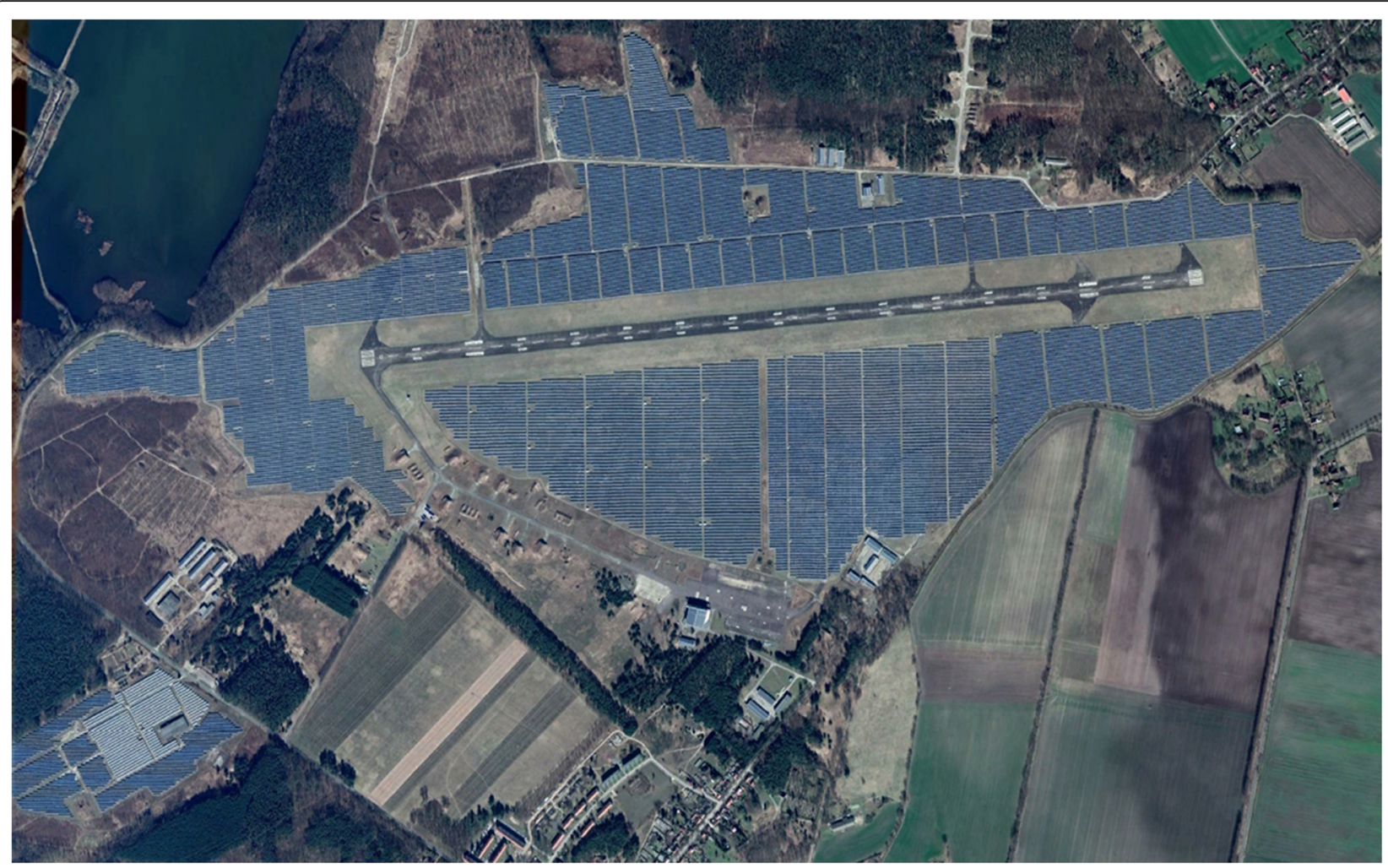

Fig. 3 Free-field photovoltaic plant with $145 \mathrm{MW}_{\mathrm{p}}$ installed on an area of 240 ha in Neuhardenberg, Germany [14] (Google Earth, 2019 [13], image recording data: 3 February 2017)

and unsolved problems concerning regulations, waste treatment, content and leaching behaviour of hazardous substances and the possible financing of decommissioning of end-of-life free-field PV plants.

\section{Materials and methods}

\section{Statistical data of photovoltaic plants in the European Union}

The statistical data of installed photovoltaic power in the EU countries from 2008 to 2017 are taken from the annual renewables reports of the EU supported EurObserv'ER [6].

The cumulated installed power, the installed power per capita and the installed power per surface area for each country are determined and graphically compared. For this case, the country's land area and population data are taken from the European Statistical Office [17].

A further set of data is used to visualise the development of the installed power of each EU country from 2008 to 2017.

\section{Mapping of free-field photovoltaic plants in Europe}

The free-field photovoltaic plants are mapped in Google Earth throughout Europe. The following sources are used to locate and map the free-field PV plants:

- Manufacturer's references by web search
- Open Street Map ITOworld [18]

- Energy Register of Greece [19]

- Direct search in Google Earth: The findings were dependent on the date of the satellite image. Almost all satellite image data of the mapped regions were between 2017 and 2019. Older image data mainly refer to remote mountain regions where no PV systems are expected. The image resolution was high enough to clearly identify the PV plants with its typical shapes, paths and inverter stations. In few cases, there could be a possibility of confusion with foil tunnels or greenhouses.

ITOworld and Energy Register do not include complete data sets of the regional PV distribution, but they are useful sources to search deeper in the respective region.

The distribution of the found free-field PV plants is compared with the map of Photovoltaic Solar Electricity Potential in European Countries provided by the European Union [20].

\section{Free-field and roof-top photovoltaic plants in South Moravia, Czech Republic}

The Czech South Moravia region in Central Europe is investigated in detail to estimate the relation between 
urban roof-top plants and rural free-field plants and their respective contribution to PV energy production and the distribution of future waste modules. South Moravia is an EU NUTS 3 territorial unit [21]. The region is chosen as it has an effective PV expansion, and the high resolution satellite images were of the same actual date.

The area is $7200 \mathrm{~km}^{2}$ with a population of 1.2 million inhabitants, whereby one-third of the population lives in the region capital Brno. The free-field plants of the region South Moravia and also the roof-top plants in the city of Brno are mapped. The following data are collected and analysed by Google mapping:

- Total number of free-field solar plants in the region of South Moravia

- Total number of roof-top plants in Brno (city boundary) and number of modules per PV plant

The sizes of roof-top plants are divided into four categories, single-family houses up to 20 modules, multifamily houses or farm houses with 21-70 modules, midscale business or communal buildings with 71-250 modules, and large-scale plants with $>250$ modules. The share of the categories is compared to the total amount of installed roof-top modules and free-field plants, respectively.

\section{Land use of free-field photovoltaic systems}

This section investigates and compares different approaches of the determination of direct land use and land occupation of renewable energy systems compared with fossil energy systems in the use phase of the life cycle based on literature data and new calculations.

\section{Hazardous substances and leaching behaviour in damaged photovoltaic modules}

PV modules can be manufactured using various technologies. This section deals with hazardous substances that may be contained in modules according to the relevant European Directives and Regulations applicable for electrical applications. Based on literature data, the type and quantity of hazardous substances are determined. A further section reviews literature on the leaching behaviour of toxic metals from broken PV module pieces.

\section{End-of-life management of photovoltaic systems}

The end-of-life management of PV systems consists of a chain of various logistical considerations and different process steps, each of which is dependent on different financial, regulatory and market conditions on national and international level. This section systematically evaluates the state of law and knowledge as well as the challenges to handle the future large mass flows of end-of- life PV modules in Europe. Based on literature, waste treatment requirements, state of the art recycling technologies, recycling fees and decommissioning costs and the question of recycling versus re-use and export are reviewed and discussed.

\section{Results and discussion}

Installed power and distribution of photovoltaic plants in the EU28

The statistical data of EurObserv'ER's Photovoltaic Barometer [6] on the installed power of PV plants are graphically prepared. Figure 4 shows the results of the EU28 per country in three expressions: total amount, per capita and per surface area.

Germany owns the highest installed power in total as well as per capita. Eighty-six percent of the total installed power is shared by six countries, Germany, Italy, the UK, France, Spain and Belgium, in that order. The PV expansion is characterised by free-field PV plants; only Belgium has a remarkable high density of roof-top plants in all scales throughout the country, which is the result of a survey in Google Earth.

The installed power per capita shows a different picture. Germany again has the highest installed power per capita, followed by Belgium, Italy, Malta, Luxemburg, Greece and the Czech Republic. The installed power per surface area is the highest by far in Malta, followed by Belgium, Germany, the Netherlands and Italy.

The total results are notable since the global irradiation in Germany, Belgium and the Netherlands is about one third less than in Italy, Greece, Spain and Portugal (see Fig. 7). Figure 5 together with the global irradiation map in Fig. 7 indicates that there is still a high potential to exploit solar energy particularly in the Southwest European countries.

Figure 5 shows the course of the annual installations of PV plants for each EU country based on the statistical data of EurObserv'ER's Photovoltaic Barometer [6] from 2008 to 2017.

In Germany, the annual installed PV power was highest between 2010 and 2012, where 53\% of the national cumulative power was installed. In Italy, $49 \%$ of the national cumulative power was installed within 1 year, in 2011. France had a slight expansion peak in 2011 and in the following years a continuous medium scale annual PV installation. Spain had an expansion peak in 2008, where $56 \%$ of the national cumulative PV power was installed. Belgium installed $71 \%$ of the national PV power from 2009 to 2012. Greece installed 58\% of the national PV power from 2011 to 2013. The Czech Republic had an expansion peak in 2010, where $68 \%$ was installed within 1 year.

The UK started a significant PV expansion in 2011 with a peak from 2014 to 2016 , where $71 \%$ of the 


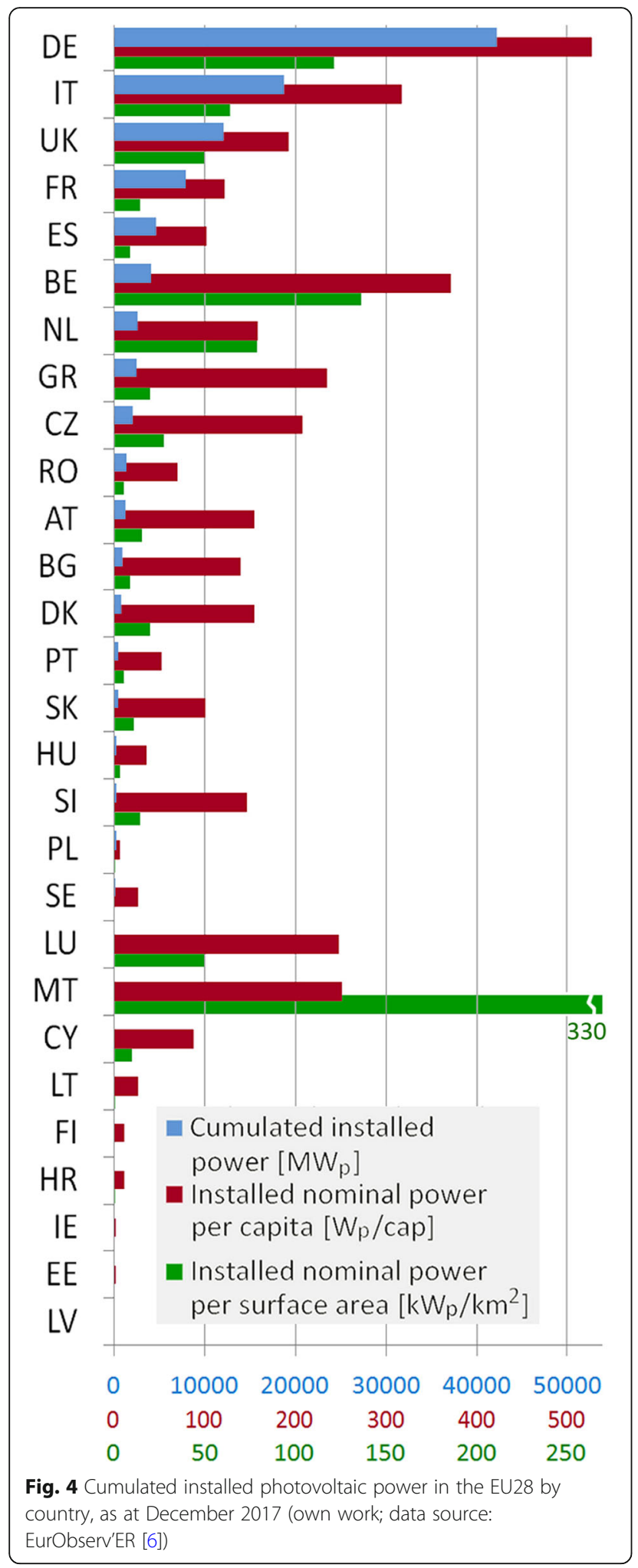

national cumulative power was installed. Bulgaria installed $69 \%$ of the national PV power in 2012 and Romania 68\% in 2013. The Netherlands started their significant PV expansion in 2012 with a continuous increase until 2017. Austria shows a relatively constant PV expansion as of 2012 on a low level. All other countries have no significant contribution to the European PV expansion.

In most EU countries, the installation activity declined due to the country-specific changing support schemes. In 2011, Europe had a total annual PV installation peak with $22 \mathrm{GW}_{\mathrm{p}}$ and in 2012 with an annual installation of $16.7 \mathrm{GW}_{\mathrm{p}}$. The UK, Sweden, Hungary, Poland and Malta show significant national PV expansion activities as of 2014, whereby except of the UK and Hungary; the total European contribution is not significant. Outside the European Union, all successor states of former Yugoslavia and Albania as well as Turkey have still a high PV expansion potential.

\section{Free-field photovoltaic plants in Europe}

Free-field PV plants are mapped in Google Earth all over Europe dependent on the actuality of the satellite image data. The first survey was from 2014 where free-field PV plants of selected European regions were mapped and published in [22, 23]. Figure 6 shows an updated and revised version as of December 2019 including approximately 17,000 mapped free-field PV plants. With the exception of a few insignificant regions, the results are representative for all EU28-countries except for the blackened regions. Our count constitutes a lower estimate of the actual number of installed free-field PV plants. The regions of Ireland and Scandinavia are not mapped. The yellow markers represent PV plants which were installed until 2014/15; the orange markers show PV plants which were installed since about 2015, though there are some overlappings due to different satellite image data. The markers represent the location of the free-field PV plants, but there is no further information about the size and the installed power, which differ significantly. The supplementary materials of this work include more detailed enlarged country images of Central Europe (Figure A1), Spain (Figure A2), Italy (Figure A3), Greece (Figure A4) and the UK (Figure A5).

The mapping results correspond well with the statistical data of Figs. 4 and 5. The mapped regions are compared with the PV solar electricity potential map in Fig. 7. The distribution of the free-field PV plants does not correspond to the solar radiation but most likely to the country-specific state funding. Hungary, Portugal, Croatia and Serbia had almost no activity; Romania and France had little activity compared to the good solar irradiation until 2015. Since 2015, a visible expansion of free-field PV plants has begun in Hungary, Poland, the Netherlands, as well as in Turkey. The UK, Germany and France show a continuous expansion until today. 


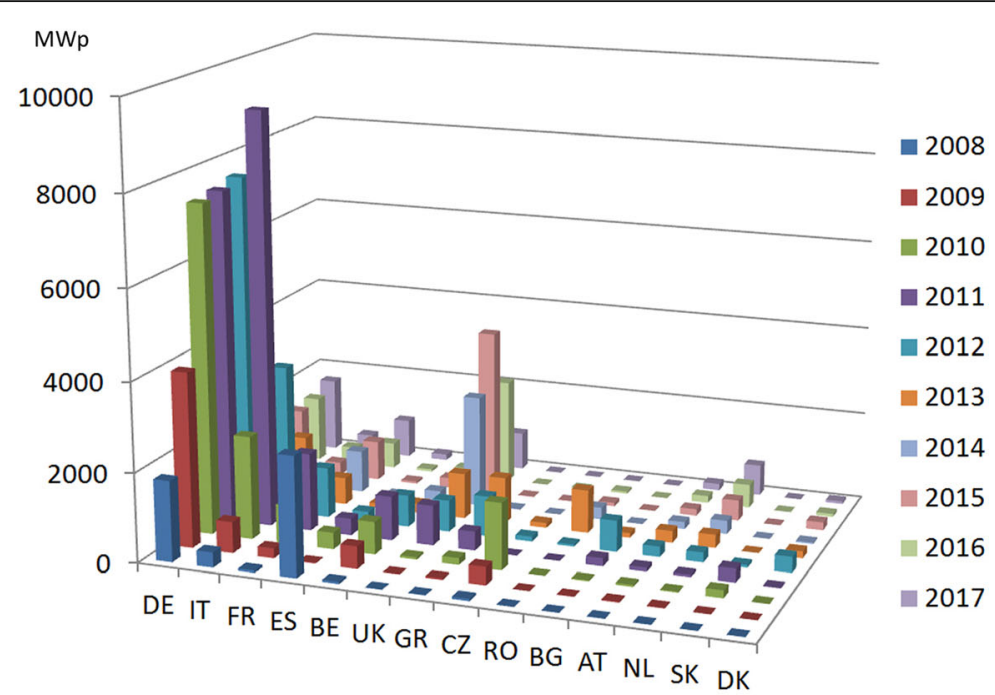

a)

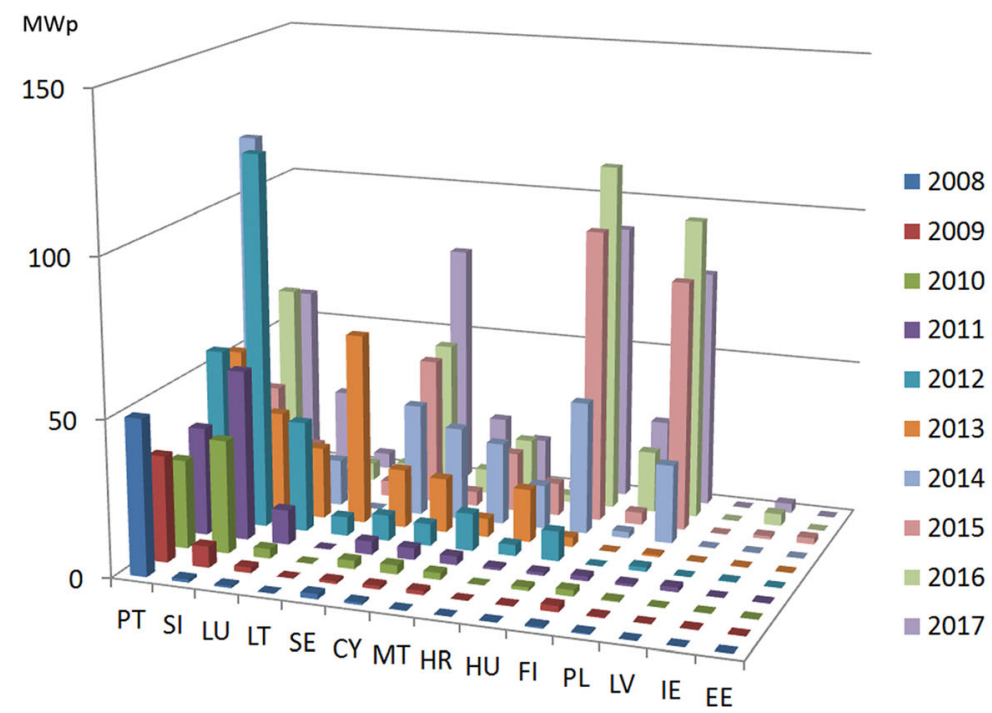

b)

Fig. 5 Annually installed photovoltaic power in $\left[\mathrm{MW}_{\mathrm{p}}\right]$ in the EU28 by country from 2008 to 2017 (own work; data source: EurObserv'ER 2010-2018 [6])

The size and locations of the free-field PV plants are different: Germany has a number of large-scale plants which are located on conversion areas such as former military airports and military training areas. PV plants are also found on former landfill sites, along railways and motor ways. In Italy and Greece, the PV plants tend to be smaller and thus larger in number. Middle and large scale PV plants are also located in not cultivated southern mountains. Nevertheless, in almost all countries, the greater part of free-field PV plants is located on former cultivated farm land.

A review in Google Earth shows that the first free-field PV plants were built far from settlement areas, but over the years they are getting closer and closer to the settlements.

Free-field and roof-top photovoltaic plants in South Moravia, Czech Republic

In the Czech Republic, as relatively small country in Central Europe, the total installed PV power is small. However, South Moravia represents a region with high installation activity from 2009 to 2010 comparable to the average in Central Europe, see Fig. 5a. Figure 8 displays all free-field PV plants in the region of South Moravia. In May 2014, the number of 185 free-field solar plants was counted. The largest one is 


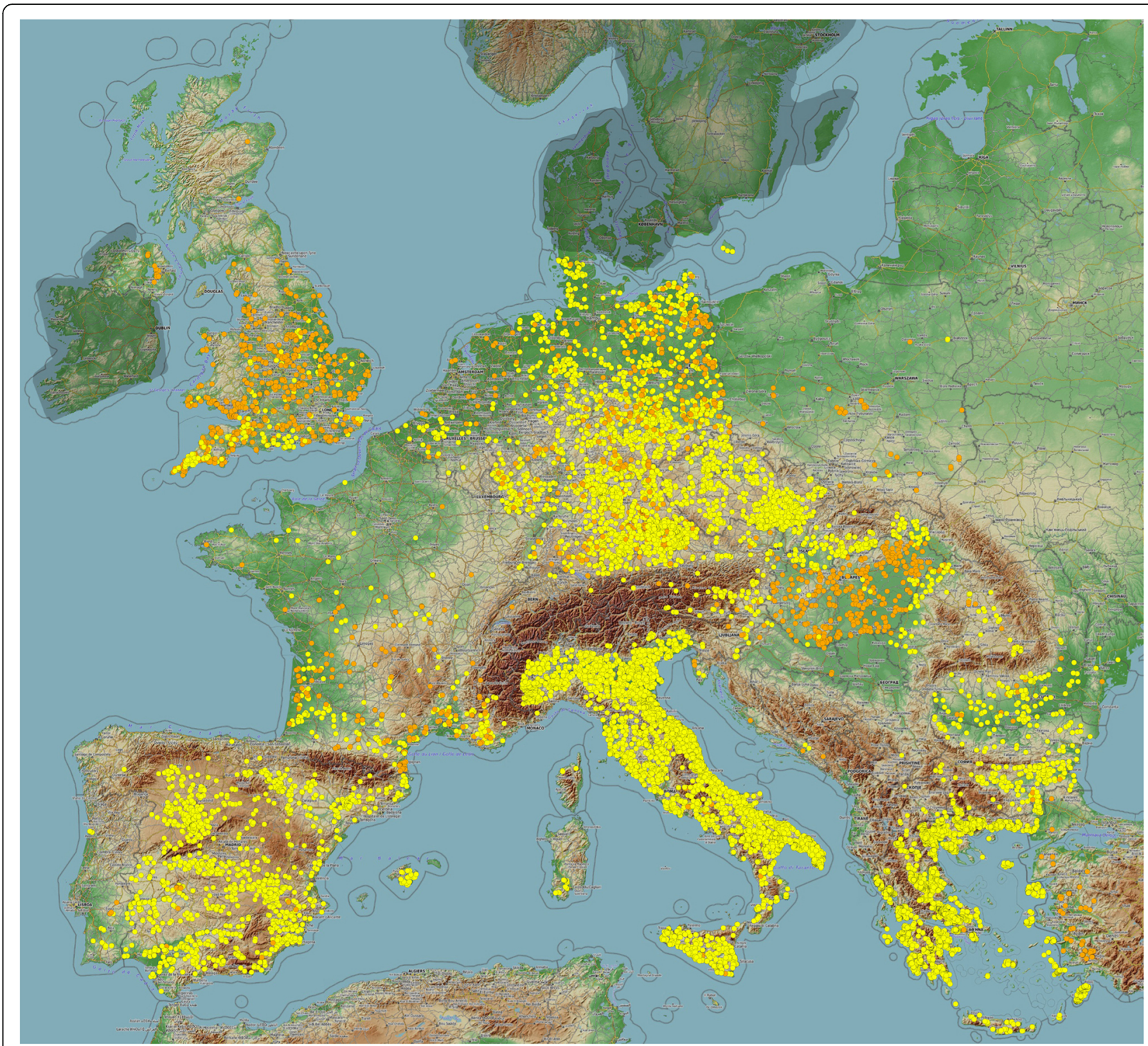

Fig. 6 Overview of mapped free-field PV plants in Europe (yellow markers: until 2014/15, orange markers since 2015), dependent on the actuality of the satellite images. The blackened areas are not representative (own work; QGIS Map: OpenTopoMap [24])

located at Brno airport (Brno Tuřany) composed of 90,000 modules with an installed power of almost 22 $\mathrm{MW}_{\mathrm{p}}$ [25]. A review in Google Earth shows that since 2014 there was no further significant activity, and the relations are still valid.

To compare the share of free-field PV plants with roof-top plants, the installed solar modules in the city of Brno (381,000 inhabitants [26]) are mapped and counted. Figure 9 shows the mapped roof-top plants as of May 2014.

The solar systems are distributed throughout the city. Besides the photovoltaic systems, also solar thermal systems are found and partly mapped. For small-scale rooftop plants, it is difficult to distinguish between the two systems only by satellite image. There is no information available about the amount and location of solar thermal systems in this region. But for the entire country of the Czech Republic in 2013, the cumulated installed capacity of thermal solar collectors was $680.6 \mathrm{MW}_{\text {th }}$ and 972,299 $\mathrm{m}^{2}$, respectively [27]. The South Moravian share is however uncertain. Table 1 lists the relevant results of the data collection.

Sixty-two percent of the counted modules belong to large-scale roof-top PV systems and $23 \%$ to the next smaller category. This means that the large number of one/two family house roof-top plants have a share of only $15 \%$ of the total roof-top PV electrical energy generation. 


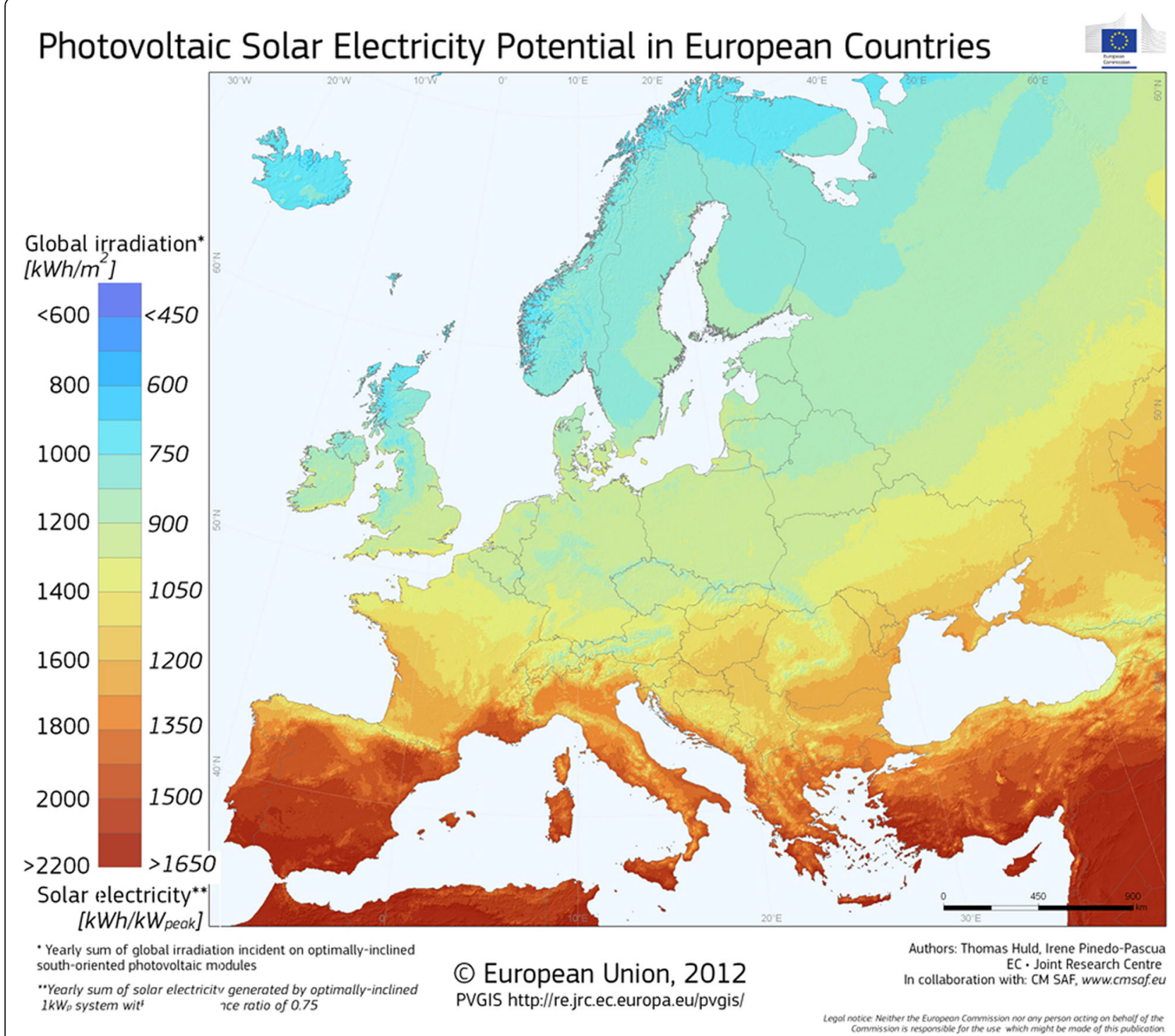

Fig. 7 Photovoltaic solar electricity potential in European countries [20]

To determine the relation between roof-top plants and free-field plants, the module number of the $22 \mathrm{MW}_{\mathrm{p}} \mathrm{PV}$ plant in Brno Airport is evaluated. It consists of 90,000 modules of different sizes. Therefore, all roof-top plants of Brno including 45,000 modules make up half the installed power of one large free-field PV plant in the region. Based on 40 roughly measured areas of randomly selected free-field PV plants in South Moravia, the total proportion of roof-top PV installations and the respective electrical energy production is estimated. Compared with all 185 free-field PV plants in the region of South Moravia, the roof-top PV plants in Brno have an estimated energy contribution of 3-5\%. In this current status, the urban PV electrical energy generation is insignificant.

\section{Land use of free-field photovoltaic systems}

Energy systems based on renewable sources are characterised by high land consumption compared to fossil energy sources. In the literature, the direct land use for the energy generation stage and the indirect land use for the manufacturing efforts and plant construction vary significantly. In 2009, a study provides direct land occupation results for energy systems [5]. The calculation method is based on one-time land transformation during a lifetime of 30 years, which means that the average land use results per kilowatt-hour are 30 times lower than if calculated annually. For comparison, the study results are recalculated for this study considering on an annual basis which conforms to growing seasons by multiplying the provided data with 30 : biomass up to $0.375 \mathrm{~m}^{2} \mathrm{a}$ / 


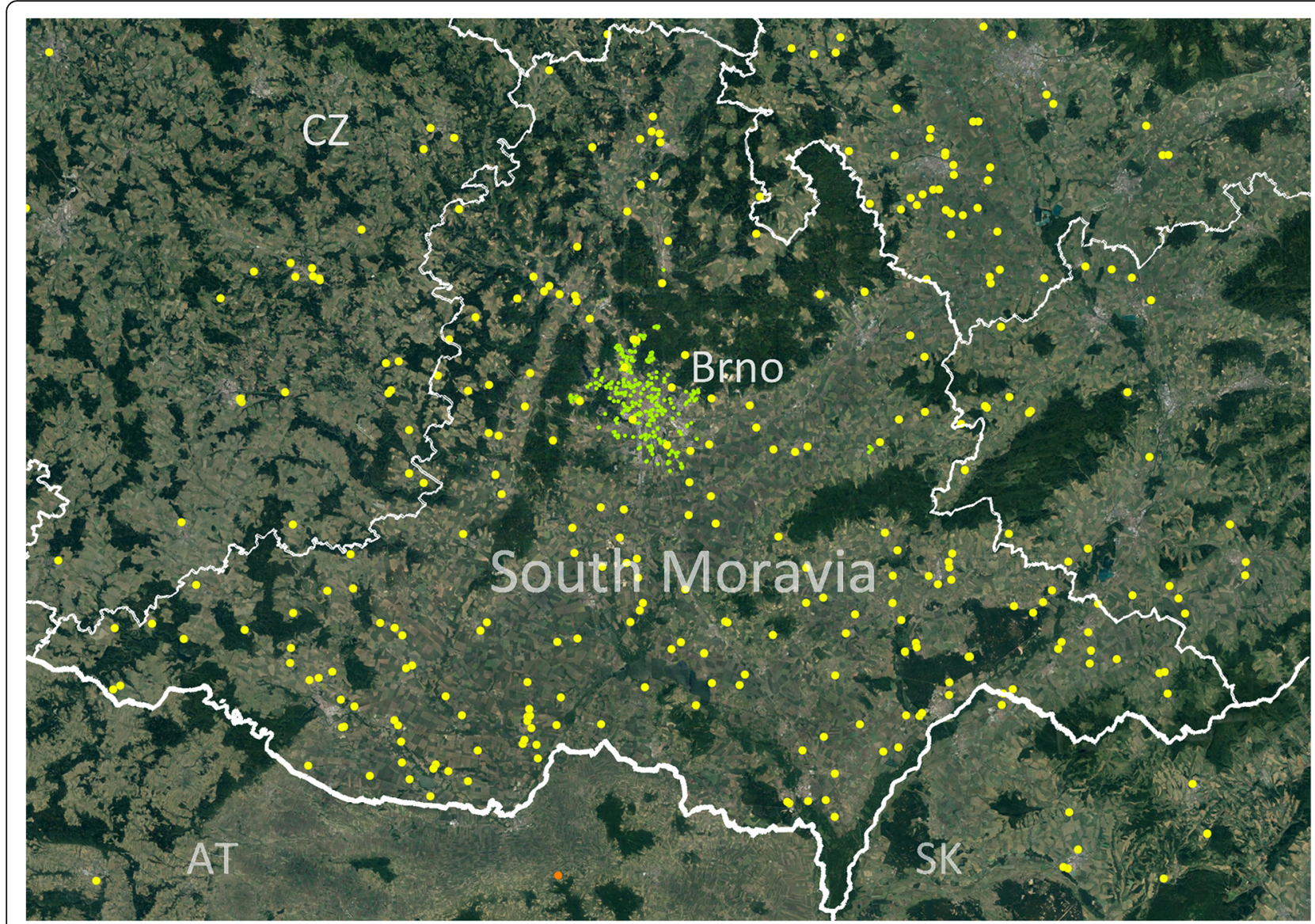

Fig. 8 Distribution of free-field photovoltaic plants (yellow markers) and roof-top plants (green markers in Brno) in the region of South Moravia, Czech Republic, May 2014 (own work; QGIS Map: Google Satellite [24])

$\mathrm{kWh}$, wind $0.063 \mathrm{~m}^{2} \mathrm{a} / \mathrm{kWh}$, PV Germany $0.021 \mathrm{~m}^{2} \mathrm{a} /$ $\mathrm{kWh}, \mathrm{PV} 0.0099 \mathrm{~m}^{2} \mathrm{a} / \mathrm{kWh}$ for an annual solar irradiance of $2400 \mathrm{kWh} / \mathrm{m}^{2}$ and surface coal mining between $0.00129 \mathrm{~m}^{2} \mathrm{a} / \mathrm{kWh}$ and $0.0252 \mathrm{~m}^{2} \mathrm{a} / \mathrm{kWh}$. Except for underground coal mining, the indirect land use data of the study are almost negligible for all systems; this also applies to PV systems.

In 2017, a further study indicates the direct land consumption for wind energy between $0.0083 \mathrm{~m}^{2} \mathrm{a} / \mathrm{kWh}$ and $0.0472 \mathrm{~m}^{2} \mathrm{a} / \mathrm{kWh}$ and free-field PV systems with 0.0192 $\mathrm{m}^{2} \mathrm{a} / \mathrm{kWh}$ [3]. The Ecoinvent database [28] for life cycle assessment does not provide life cycle inventory data for the direct land use of energy systems. The LCA results of agricultural land occupation for indirect land use, i.e. for the construction of the plants, for Austria based on Ecoinvent 3.4 [28] are higher than in [5]. The results according to the LCI data of [28] are biogas $0.0085 \mathrm{~m}^{2} \mathrm{a} /$ $\mathrm{kWh}$, PV systems $0.0048 \mathrm{~m}^{2} \mathrm{a} / \mathrm{kWh}$, lignite by surface mining $0.00153 \mathrm{~m}^{2} \mathrm{a} / \mathrm{kWh}$ and hard coal by underground mining $0.0137 \mathrm{~m}^{2} \mathrm{a} / \mathrm{kWh}$. Furthermore, the total area of direct and indirect land use for Austria was determined. The results are $0.313 \mathrm{~m}^{2} \mathrm{a} / \mathrm{kWh}$ for biomass power and heat based on maize and $0.0277 \mathrm{~m}^{2} \mathrm{a} / \mathrm{kWh}$ for a freefield PV system located in an area with an annual solar irradiance of $1200 \mathrm{kWh} / \mathrm{m}^{2}$ [4].

It is important to distinguish between one-time land transformation over the energy system operation time and the land occupation during each annual vegetation season. If only the one-time land transformation is taken into account, the average land use results per generated kilowatt-hour are significantly lower, and the annual competition for land is not properly reflected. Considering further the time in which the transformed land returns to its original state, the real land occupation is additionally increased. Agricultural areas that are transformed into PV or wind areas are little affected when the energy systems are decommissioned. The situation is different with hydropower, fossil and nuclear energy systems. Coal mines are assumed to have an operating lifetime of 30 years and a subsequent land reclamation period up to 250 years. Furthermore, land consumption by secondary effects such as disturbing the natural balance of forests and ground water as well as water contamination should also be taken into account [5]. 


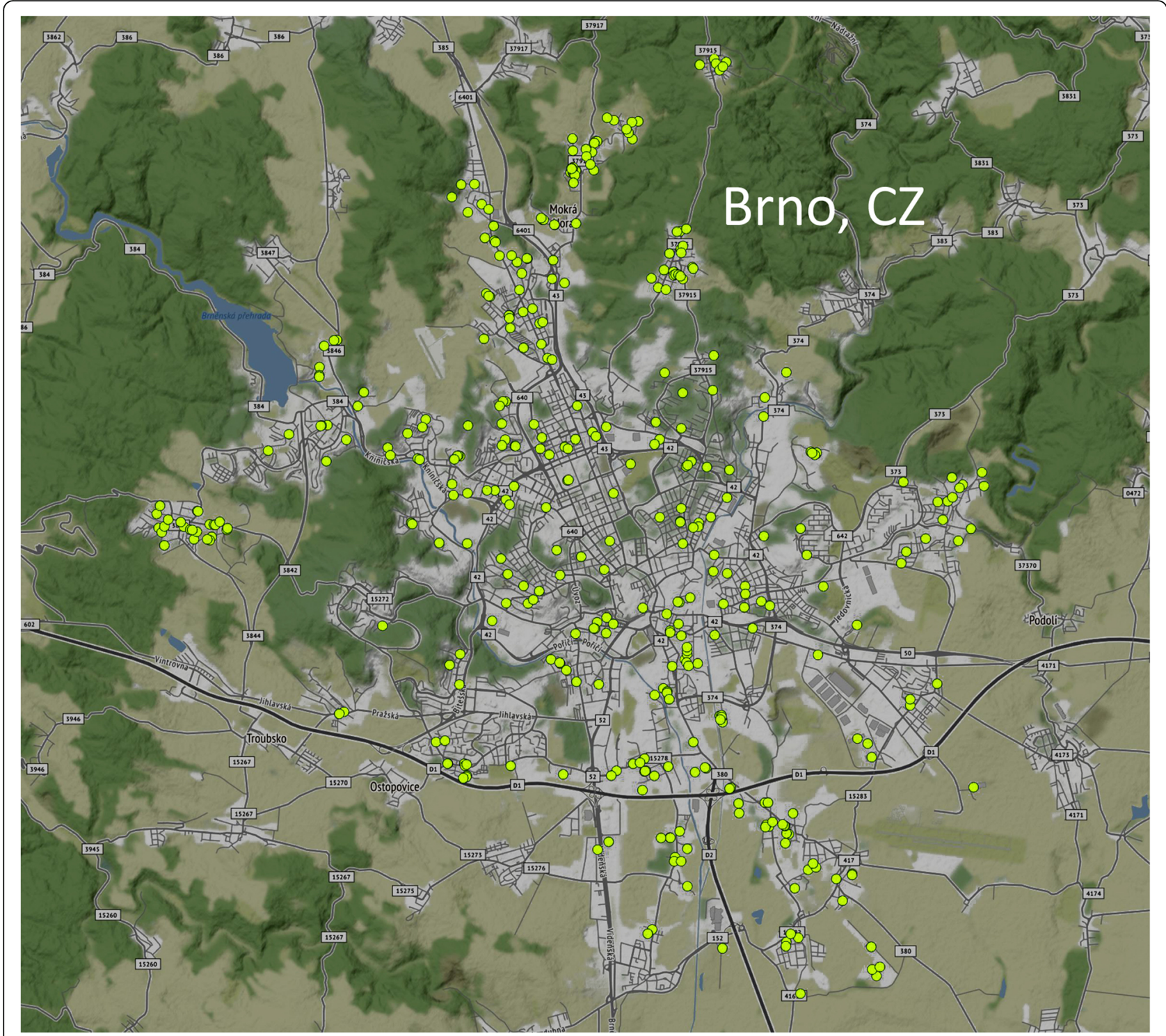

Fig. 9 Roof-top solar plants (green pins) in Brno, May 2014 (own work; QGIS Map: Stamen Terrain [24])

Besides general considerations about the land use and reclamation time, in 2013, a study developed a multilevel classification of more than 100 classes and subclasses of land use including levels of detail ranging from general global land cover classes to specific regionalised land use and cover classifications. Examples are terrestrial, freshwater and marine biomes which are further specified from climate regions and ecoregions to geo- referenced information of land use/cover such as forest and grass land types, agricultural types, urban area types or different water bodies [29].

The European Product Environmental Footprint Category Rules (PEFCR) [30] provide detailed and comprehensive technical guidance on how to conduct a Product Environmental Footprint (PEF) study for PV modules used in PV systems for electrical energy generation. The

Table 1 Determined roof-top solar systems in Brno, May 2014

\begin{tabular}{llll}
\hline $\begin{array}{l}\text { Total } \\
\text { number } \\
\text { of solar } \\
\text { modules }\end{array}$ & Number of PV systems with & & \\
\cline { 2 - 4 } & $2-20$ modules & $21-70$ modules & $71-250$ modules \\
\hline 45,000 & 151 & 122 & 80 \\
\hline
\end{tabular}


impact categories to be used to calculate the PEF profile of PV modules include the category 'land use' with the indicators biotic production, erosion resistance, mechanical filtration (of water) and groundwater replenishment in connection with the manufacturing of the PV modules, which are aggregated to a dimensionless index. The defined functional unit is $1 \mathrm{kWh}$ of DC electrical energy at the outlet of the DC connector attached to the junction box of the PV module. The service life of the PV plant is defined with 30 years. The use stage of the life cycle should be modelled based on an optimally oriented module mounted on a slanted roof in Europe. The PEFC $\mathrm{R}$ guide explicitly limits the LCA results for comparison of different PV modules and point out that the scope of the LCA guide does not include comparisons of real installations neither of roof-top plants of different locations and module orientations nor with other energy systems.

\section{Hazardous substances and substances of very high concern in photovoltaic modules}

PV modules may contain a number of hazardous substances which are regulated by the European RoHS Directive [31], the REACH Regulation for chemicals [32], the CLP Regulation for labelling of substances [33] and those that are included in the European Chemicals Agency (ECHA) Candidate List of substances of very high concern (SVHC) [34]. All REACH and REACH Candidate substances carry immediate obligation for suppliers of the substance such as supplying a safety data sheet and communicating on safe use. Further ECHA has to be notified if a product contains a SVHC above a concentration of $0.1 \%(w / w)$. The RoHS Directive regulates the limitation of lead, mercury, chromium (VI), brominated flame retardants and a selection of phthalates of which max. $0.1 \%(\mathrm{w} / \mathrm{w})$ each as well as cadmium $\max .0 .01 \%(\mathrm{w} / \mathrm{w})$ is allowed to be included in electrical and electronic products. While the RoHS Directive, which excludes PV modules that are installed by professionals for permanent energy generation, defines the maximum concentration values of the regulated hazardous substances in 'homogeneous materials' that cannot be disjointed by mechanical actions, the REACH Regulation makes no further distinction in the material composition and disassembility or disjointability of the product. Since PV modules have a large glass fraction of the front cover and for some technologies front and back cover, the content of hazardous substances in the thin active layer may remain under the limit value of $0.1 \%$ of the total mass, although the PV module laminate is not a homogeneous material. The REACH Regulation requires the registration of articles if a product contains more than $0.1 \%(\mathrm{w} / \mathrm{w})$ of a hazardous substance and the substance is intended to be released under normal or reasonable foreseeable conditions of use'. However, the hazardous substances included in PV modules are not intended to be released, and therefore, a number of studies were performed investigating the leaching behaviour of hazardous substances of PV modules in operation and in damaged PV modules, which is discussed in the next section.

The REACH Regulation includes substances and compounds which may be included in thin film PV modules such as cadmium telluride and selenium which is alloyed into the $\mathrm{CdTe}$ absorber to increase the cell efficiency [35]. Concerning the SVHC Candidate List, PV modules may contain cadmium sulphide in the semiconductor layer, lead in solder and metallisation, and diarsenic trioxide in the module glass [36] and cadmium nitrate in solar cells [37]. CLP Regulation relevant substances include plasticisers used in cables, flame retardants used in inverter PCBs, diantimony trioxide in crystalline module glass as well as titanium dioxide and zinc dioxide used for antisoiling properties [36].

In the literature, different information can be found about the quantity of hazardous substances included in PV modules. One publication reports that silicon-based PV modules contain $10-20 \mathrm{~g}$ toxic lead per module, which is part of the solder the metallisation [38]. The module area is not mentioned, but assuming a standard module area of $1.6 \mathrm{~m}^{2}$, the lead content is $6.25-12.5 \mathrm{~g} / \mathrm{m}^{2}$. Another publication indicates that the content of $\mathrm{CdTe}$ amounts to $18 \mathrm{~g} / \mathrm{m}^{2}$ [39]. The results of a further study show that c-Si modules contain $6.32-6.68 \mathrm{~g} / \mathrm{m}^{2}$ lead, CdTe modules contain $5.56-7.88 \mathrm{~g} / \mathrm{m}^{2}$ cadmium and $6.24-8.4 \mathrm{~g} / \mathrm{m}^{2}$ tellurium in compounds and CIGS modules contain $5.64 \mathrm{~g} / \mathrm{m}^{2}$ indium [40]. A similar amount of cadmium is provided in a further study that reports $6 \mathrm{~g} \mathrm{Cd}$ per module of $0.72 \mathrm{~m}^{2}$, that is $8.3 \mathrm{~g} / \mathrm{m}^{2}$ [41].

The 2009 Ecoinvent report on photovoltaics provides following life cycle inventory data for PV modules: For silicon-based PV modules, the front side metallisation paste includes $5 \%$ lead, and the back side metallisation paste includes $8 \%$ lead. Further, the PV module includes $7.40 \mathrm{~g} / \mathrm{m}^{2}$ of front side metallisation paste and $4.93 \mathrm{~g} / \mathrm{m}^{2}$ of back side metallisation paste. Therefore, the total mass of lead of the metallisation results to $0.76 \mathrm{~g} / \mathrm{m}^{2}$. CdTe modules include $3.52 \mathrm{~g} / \mathrm{m}^{2}$ cadmium sulphide, $43.4 \mathrm{~g} / \mathrm{m}^{2}$ cadmium telluride and $0.71 \mathrm{~g} / \mathrm{m}^{2}$ lead. These life cycle inventory data are used in the Ecoinvent database, and particularly the value for cadmium telluride should be reviewed for newer technologies. There are no LCI datasets available for modules containing a larger amount of lead [42].

\section{Leaching behaviour of damaged photovoltaic modules}

Photovoltaic modules may contain a number of toxic substances, mainly metals, in small quantities 
depending on the technology type and generation of technology [43]. Under normal operating conditions of a PV plant, no hazardous substances are released from the semiconductor layers since they are chemically bound in the active layer and further embedded in the laminate and encapsulated against environmental influences. But in case of accidental breakage [44] or during end-of-life treatment of the PV module, liquids such as rainwater or landfill leachate can dissolve hazardous substances from the exposed edges. Whether the broken module is classified as hazardous or non-hazardous waste is determined by the concentration of metals during a standardised test procedure designed to simulate such leaching behaviour. There is a broad scientific discussion about the leakage behaviour of damaged PV modules in general and the suitability of standard test procedures, which is briefly summarised here [45-47].

The first studies by $[45,48]$ on leakage from $\mathrm{CdTe}$ and CIS modules were already carried out in the 1990s where worst-case metal concentrations from accidentally damaged thin-film modules were estimated. Weekly amounts of rainwater were exposed to crushed $0.5 \mathrm{~m}^{2}$ modules. Metal concentrations in these leachates showed higher aquatic toxicity for CdTe than for CIS modules, but both had a toxicity comparable to that of industrial wastewater. These concentrations were further used to estimate concentrations in two hypothetical scenarios: (a) water collected from a roof-top containing one broken module and (b) soil underneath a broken module resting on the ground for 1 year. Estimated zinc and cadmium concentrations in roof-top water from the CIS module were approximately two orders of magnitude below the German drinking water standard, and the selenium concentration was one order of magnitude lower. Cadmium from the $\mathrm{CdTe}$ modules was of the same order of magnitude as the drinking water standard. Leaving a broken module on soil for 1 year was estimated to increase soil concentrations by the same order of magnitude as the natural ranges of metals concentrations present in soil in most cases. With the exception of molybdenum, the increases were well below tolerable soil levels. The same author notes that the amount of metals released from accidentally damaged modules during their use can be expected to be orders of magnitude lower than the metals contained in waste modules after their use. Regulatory leaching tests for waste characterisation (German, Swiss, and the USA) showed that a CIS module only exceeded the zinc limit of the Swiss test, while a CdTe failed all three tests due to cadmium release.

In 2010, a Norwegian study [49] also investigated the leaching behaviour of $\mathrm{CdTe}$ modules. Their literature search revealed little on the human toxicity and nothing on the ecotoxicity of CdTe, but leaching tests showed higher mobilisation of tellurium than cadmium at a $\mathrm{pH}$ of 9.6, since cadmium is re-precipitated. Cadmium concentrations in leachate exceeded the limits for inert waste landfills, and the authors expected $\mathrm{Cd}$ to also exceed the limits for ordinary landfills at lower $\mathrm{pH}$ values. The study concludes that there is not currently enough documentation to assess the fate and toxicity during the use and disposal of $\mathrm{CdTe}$ modules. The authors recommend leachate tests, particularly at lower $\mathrm{pH}$ values.

A 2013 study by [50] analysed long-term leaching of metals and metalloids from damaged CIGS and organic PV (OPV) modules into different model waters and calculated environmental concentrations for several scenarios. While metals released by OPV were of little toxicological concern and far below conservative drinking water standards, roof-top acidic runoff from CIGS modules exhibited significant toxicity: leached cadmium concentrations from cadmium sulphide in the window layer would considerably exceed the acute toxicity concentrations for Daphnia magna (daphnia or water fleas are sensitive to pollutants in the water), and the calculated selenium and molybdenum concentrations were in the range for teratogenic effects. Both cadmium and lead leaching were mainly governed by the $\mathrm{pH}$ of the leaching solvent but not as much by the size of module pieces. Long-term experiments over a period of several weeks were considered by the authors to be most realistic, calling into question the results from current short-duration regulatory leaching protocols. The authors conclude by noting the high amount of lead from solder in c-Si modules that is of concern due to the dominant market share of this PV technology.

An earlier fate and exposure study by [41] was limited to cadmium from CdTe modules. The study considered a scenario of all cadmium in a broken roof-top array being swept by total annual rainfall amounts into the soil underneath the roof downspouts. These workers calculated concentrations at exposure points of air, soil and groundwater both for on-site workers and off-site residents with conservative assumptions (except for a neutral groundwater $\mathrm{pH}$; when assuming a more acidic $\mathrm{pH}$, the rainwater $\mathrm{pH}$ might have increased the estimated groundwater concentrations). Exposure to air and soil was found to be orders of magnitude below both Californian and German screening levels, while groundwater equilibrium concentrations were below both screening levels and background concentrations. The same research group also conducted an evaluation [51] of standard waste characterisation leaching tests in the USA, Germany and Japan with regard to their suitability for assessing the potential environmental impacts of $\mathrm{CdTe}$ module field breakage. They concluded that waste leaching tests may reflect conditions during a recycling 
process but can be more aggressive than PV field breakage conditions when it comes to particle size, solvent $\mathrm{pH}$ and treatment method.

Similarly to [51], another study [46] investigated the applicability of two US standard waste characterisation leaching tests to the leaching behaviour of PV waste (mc-Si and CIGS). The authors found that lead concentrations from mc-Si cells and modules exceeded the regulatory limit but only when measured for longer periods than specified by the standard tests. Leaching from CIGS modules exhibited similarly slow leaching of copper and selenium to eventually exceed regulatory limits. The authors attributed the slower leaching kinetics to the layering of the material. They concluded that the tested methods may not be valid for characterizing PV waste in landfills, and additional testing is needed to accomplish that.

A 2015 US study [47] investigated the behaviour of ground solid CdTe and CdSe in aqueous solutions simulating landfill leachate under two standard waste leaching test used by the USA and the California Environmental Protection Agencies. They found cadmium concentrations from CdTe that were 1500 and 260 times higher than the regulatory limit for the two test protocols. The authors also investigated the effect of different redox and $\mathrm{pH}$ combinations on the leachability and determined that acidic and aerobic conditions markedly increased the dissolution of both $\mathrm{CdTe}$ and CdSe, in keeping with thermodynamic predictions. Consequently, the authors recommend the recycling of $\mathrm{CdTe}$ containing devices rather than their landfilling. A comment to this study by [52] argues that the initial concentration of $\mathrm{CdTe}$ in actual PV modules would be approximately three orders of magnitude lower than the concentrations used in the [47] study, with encapsulation further limiting the leaching potential. They also note that CdTe PV modules are being recycled commercially since 2005 , with a $95 \%$ recovery of $\mathrm{CdTe}$ thin films.

In 2017, a German study [53] investigated the longterm leaching of metals from silicon (crystalline, with at least one $\mathrm{Pb}$-containing solder ribbon; and amorphous), $\mathrm{CdTe}$ and CIGS photovoltaic modules. Two small $(5 \times$ $5 \mathrm{~cm}^{2}$ ) squares from the same module material were immersed in a buffered aqueous solution, at $\mathrm{pH}$ values of 3,7 and 11, respectively. This was repeated for the other module materials, each experiment in triplicate. After 360 days, they found significant leaching in the acidic and oxidizing solutions. In particular, 1.4\% (by mass) of the lead in the c-Si modules, and $62 \%$ of the cadmium in the CdTe modules is leached out in the $\mathrm{pH}$ $=3$ solution. These amounts exceed the WHO standards for drinking water concentrations of the respective metals. The leached amounts after 1 day were at least 2 orders of magnitude lower, leading the authors to challenge the meaningfulness of short-term leaching tests. These results are questioned by Sinha and Wade [54] who argue-among other points-that the use of citrate as a buffering agent and its chelating action may have led to higher metals concentrations than would be found in acidic rainwater. In a commentary, the authors of the original study [53] have replied [55] that the type of counter ion used will not change the high sensitivity to the leachate $\mathrm{pH}$.

The same research group investigated metals leached from milled $(<0.2 \mathrm{~mm}) \mathrm{PV}$ modules as a function of time and of the $\mathrm{pH}$ of the leachate [56]. They report severe leaching of metals over the course of 8 weeks and found that $50 \%$ of the $\mathrm{Cd}$ in $\mathrm{CdTe}$ modules, and more than $15 \%$ of $\mathrm{Pb}$ in $\mathrm{c}-\mathrm{Si}$ modules was leached out after 56 days when exposed to a 'rainwater-like' solution of $\mathrm{pH}=$ 3 , rising to $\mathrm{pH}=5$ and 6 , respectively, after 56 days. The leached amounts rose steadily during that time.

For emerging PV technologies, such as perovskite solar cells (PSCs), copper zinc tin sulphide (CZTS) and lead sulphide quantum dot solar cells (QDSCs), a study described in [57] investigated the life cycle toxicity of metals that are contained in water soluble components of these cells. The authors modelled leaching during the PV use phase by assuming a crack in the panel and accounting for the physiochemical properties of the metals. For copper and lead, the authors found a higher toxicity from damaged panels during the use phase than during the mining phase of these metals.

A recent study by [58] discusses the findings of previous leaching studies, citing $[49,56]$. The authors note that-in addition to presenting equivocal results-both sources are laboratory studies and may not reflect the operating conditions in the field. Consequently, the authors analysed soil samples for bioavailable metal concentrations in the field, from an operational $750-\mathrm{kW}$ cSi PV installation that had been in operation for 5 years prior to sampling. They sampled three transects, one $30.48 \mathrm{~m}$ away and two directly underneath the PV panels. Neither cadmium nor lead soil concentrations were different between the transects, but selenium, strontium and barium increased markedly underneath the panels, while copper and zinc even decreased significantly. Selenium in particular approached the US regulatory risk threshold. However, selenium is not used in cSi modules, and the authors suggest cement from panel foundations as a more likely source. They identified a need for more research on metal and metalloid soil burdens from the operation phase of PV panels.

\section{End-of-life management of photovoltaic systems}

The end-of-life (EoL) management of PV modules is regulated by the European e-waste Directive [10]. It 
covers all EEE used by consumers and EEE intended for professional use. It also explicitly includes photovoltaic panels. The terms 'waste electrical and electronic equipment' or 'WEEE' mean electrical or electronic equipment which is waste within the meaning of any substance or object which the holder discards or intends or is required to discard. It includes all components, subassemblies and consumables which are part of the product at the time of discarding [10,59].

The e-waste Directive mandates that all WEEE have to be returned to convenient facilities, and they have to be accepted free of charge. The first facility of the end-of-life management chain covered by the e-waste Directive is as general rule the 'gate' of a registered regional collection scheme. It is prohibited that collected e-waste is disposed without undergoing proper treatment [10].

\section{Waste treatment requirements for WEEE}

The waste treatment of PV modules is regulated in several standards and technical specifications [10, 60-74]. Standard EN 50625-1 [63] regulates the general treatment requirements for collection, logistics and treatment of WEEE. PV modules have to be treated with special care and attention to avoid injury by broken glass as well as by electrical shock through dangerous voltage generated if the PV modules are exposed to light. The stored amount of WEEE of a treatment plant must only be as much as can be processed within 1 year. The sites for storage have to feature impermeable surfaces and weatherproof covering. The first waste treatment steps include, i.e. the removal of external electrical wiring and the removal of plastics with brominated flame retardants. Since PV modules are not covered by the RoHS Directive [31], it must be assumed that they contain brominated flame retardants in accordance with Appendix A.6.3.1 of the standard, unless there is explicit evidence that this is not the case.

The specific treatment requirements for photovoltaic panels are regulated in the standard EN 50625-2-4 [69]. It includes the separation between silicon-based and non-silicon-based PV modules and further the separation of the PV modules into different material fractions such as glass, metals, plastics and semiconductor layers. Generally, silicon-based and non-silicon-based PV modules are distinguishable by visual inspection; however, amorphous silicon (a-Si) panels may not be distinguished from non-silicon-based PV panels. The type plates of the PV system can be used to identify the material composition of the modules in the PHOTON database [75].

Silicon-based PV modules can contain hazardous substances such as lead, lead oxide and fluorine. The separation of metallic lead or lead-based solder can be carried out by eddy current devices, induction sorting systems or optical/electrical sorting systems. Non-silicon-based PV modules can contain lead, cadmium, cadmium sulphide, selenium and fluorine. The treatment has to ensure that hazardous substances are removed from the semiconductor layer including the electrical contacts. The removal of lead, selenium, indium (as valuable material) and cadmium could be carried out by chemical and physical treatment, which is not further described [69].

The technical specification for de-pollution of PV modules is regulated in the pre-standard DIN CLC/TS 50625-3-5 [70], supplementing the standards [63, 69]. It regulates the normative requirements such as target values and limit values of analysis for the glass fraction, which is returned to the material cycle. The limit values for the dry mass of the glass fraction of silicon-based PV modules are $1 \mathrm{mg} / \mathrm{kg}$ cadmium and selenium, respectively, and $100 \mathrm{mg} / \mathrm{kg}$ lead. The limit values for the dry mass of the glass fraction of non-silicon-based PV modules are $10 \mathrm{mg} / \mathrm{kg}$ cadmium and selenium, respectively, and $100 \mathrm{mg} / \mathrm{kg}$ lead. The limit values for cadmium and selenium represent the removal and separation of $95 \%$ of the semiconductor layer [70].

\section{The state of the art recycling technology for photovoltaic modules}

The state of the art of PV module recycling includes that after removing the junction box and the aluminium frame; the modules are shredded or crushed. The glass fraction is prepared for re-use for low quality applications such as glass wool. The EVA foil undergoes thermal treatment by incineration. Silver and indium compounds and metals are refined [76].

The current minimum recovery targets for PV modules are that $85 \%$ should be recovered, and $80 \%$ should be prepared for re-use and recycling [10]. The recovery targets however solely relate to glass and aluminium recycling. The main economical and technological challenge of the PV recycling process is the delamination, separation and purification of silicon from EVA/glass and the semiconductor thin film of other module technologies from the front/back sheet glass, respectively [76]. In case of Si-based PV modules, all non-Si layers, that is metallisation, antireflection coating, emitter and back surface field, have to be etched away before the silicon can be used for the ingot growing [77].

Currently, silicon recovered from primary recycling of both kerf and EoL PV-modules has low quality and cannot be used for the production of silicon wafers. The research aim is to produce secondary silicon with a purity of, e.g., 99.9999\% with a lower carbon footprint than virgin silicon material [78]. One of the major technological and economical challenges is the recovery of pure 
silicon, which has to be separated from adhesives, metallisations and other impurities, to gain high quality raw materials for new silicon wafers. The research trends for EoL Si-PV modules treatment are towards chemical recovery or different combinations of mechanical, chemical and thermal recovery [79].

A comprehensive summary and patent review of global recycling technology trends for PV modules can be found in the IEA PVS-Report [79]. A further systematic quantitative literature review investigated 70 research papers with regard to EoL treatment and management of PV plants. The reviewed studies cover waste treatment, policy and management, the projection of PV waste generation, reverse logistics and life cycle assessment. Critical recycling challenges are, e.g., the reduction of gas emissions and temperature during the delamination process, decreasing of chemicals utilisation and chemical waste production and achieving a high level of purification. The authors note that end-of-life studies are mostly conducted in laboratory settings and that results are lacking for forecasts of PV waste streams, suitable recycling technologies and waste logistics and policies [80]. A further EoL review study also included battery storage systems. The authors identified a trend away from the dominance of experimental end-of-life studies towards modelling and simulation studies [81].

In the European Union, the end-of-life management and legal compliances service of PV modules is offered by the association PV CYCLE, which is significantly involved in research activities for new recycling technologies and decommissioning logistics [82].

\section{Recycling fees and decommissioning costs}

In general, the costs for the end-of-life treatment and recycling of e-waste are paid in advance by the manufacturer in the EU. However, the fees cover the costs of the waste treatment only from the beginning of the collection scheme [10] excluding the dismantling and the transport to the collection site. To compare recycling costs of e-waste, in Austria, examples of the fees without tax for household appliances are the following: $€ 5.80$ per piece for screens and monitors with a mass of 10 to $25 \mathrm{~kg}, € 6.10$ per piece for temperature exchange equipment, $€ 0.17$ per piece for (other) large appliances with a mass of 6 to $30 \mathrm{~kg}$. The fees for commercial appliances are 15 to $30 \%$ less. The recycling fees for lithium batteries are $€ 0.61$ per kilogramme [83].

In the EU, the logistics and the economical implementation of end-of-life PV modules are still under development and depend on the profitable recovery of the waste fractions. The main material fractions of Si-based PV modules are about $70 \%$ glass, $13 \%$ aluminium, $11 \%$ polymer, $3 \%$ silicon, $1 \%$ copper, $2 \%$ junction box and $0.03 \%$ silver. Thereof, the highest economic values of the recycled materials consist of estimated $45.4 \%$ for silicon, $24.6 \%$ for silver and $18.6 \%$ for aluminium. The glass fraction only represents an economic value of 4.9\% [76]. The glass fraction of frameless CdTe PV modules has a mass share of 95\% [84].

Two financially and legally independent procedures have to be developed for future large-scale end-of-life management of free-field PV plants in Europe: On the one hand, according to WEEE, the fee covering the recycling costs for the manufacturer has to be determined. On the other hand, local logistics and finance models have to be developed to ensure decommissioning and transport of end-of-life free-field PV plants. It can be expected that a significant number of PV plant owners will have no financial reserves to cover decommissioning and transport costs in about 20 years when fields of the first PV installation peak in Europe from 2010 to 2012, see Fig. 5, face decommissioning.

Future PV module recycling logistics include different models, such as mobile recycling systems in form of trucks which are temporarily installed near the free-field PV systems, or large centralised recycling plants located near PV manufacturers or near glass manufacturers to optimise transportation efforts and emissions [76]. However, it must be taken into account that in each case, local permits for the temporary installation of the mobile recycling system must be clarified.

There is little literature on the costs of decommissioning, transport and disposing or recycling of PV systems. A Swiss study developed a new financial model to determine the optimal time and location to invest in PV module recycling systems in the USA including different parameters such as time-dependent storage and treatment costs and market prices for recovered materials, transportation, utilisation rate and recycling yields of PV module material fractions for different scenarios [85].

The EU research project CABRISS calculated a scenario for average transportation costs for dismantled PV modules to the next glass recycling system in the EU. Within a radius of $500 \mathrm{~km}$, the costs result to $250 \mathrm{EUR} / \mathrm{t}$ based on average costs of $0.5 \mathrm{EUR} / \mathrm{tkm}$ [78].

The New York Solar Guide Book recommends landowners who lease their land to contractually make sure that there are provisions that determine who is responsible for dismantling the PV system if the company is no longer in business or if the PV system is at its end of life, ensuring the property is returned to its pre-leased condition. The estimated current costs of decommissioning are USD 60,200 for a $2 \mathrm{MW}$ free-field PV system. Thereof, USD 2250 are estimated for the transportation to the recycling centre [86]. The Resources for the Future (RFF)-Report provides estimations of the decommissioning costs for PV systems between USD - 89,000 to USD 179,000 per MW installed power. The negative 
cost estimates indicate that the salvage value of the materials exceeds the decommissioning costs [87].

A further study presents the results of different decommissioning scenarios for large-scale PV plants based on a free-field PV plant with 2711 modules/MW with a module area of $2.47 \mathrm{~m}^{2} /$ module and a mass of 35 $\mathrm{kg} /$ module installed on an area of 7.1 acres $/ \mathrm{MW}_{\mathrm{ac}}(=$ $2.87 \mathrm{ha} / \mathrm{MW}_{\mathrm{ac}}$ ). The direct and indirect decommissioning costs vary between USD 123,600 and USD 151,000 per $\mathrm{MW}_{\mathrm{ac}}$ plus recycling costs of about USD 32,000 and landfill costs for the residual PV plant materials of USD 6000 per $\mathrm{MW}_{\mathrm{ac}}$, respectively. This compares with an estimated scrap value of steel, copper and aluminium between USD 109,000 and USD 220,000 per $\mathrm{MW}_{\mathrm{ac}}$. Excluding the land value, the net decommissioning costs are between USD - 79,400 and USD + 54,200 per $M W_{a c}$, whereby the negative value represents the net profit. Otherwise expressed, the recycling costs are estimated with USD 0.34 (= EUR 0.31) per kilogramme module, and the scrap value of the entire decommissioned PV plant referred to $1 \mathrm{~kg}$ module unit is between USD 1.15 and USD 2.32 (= EUR 1.06 and EUR 2.14) per kilogramme module. The scenarios with a net profit are only achievable by the removal and recycling of steel, copper and copper cables. The provided data for copper are $1.166 \mathrm{~kg} / \mathrm{m}^{2} /$ module, $5001 \mathrm{~kg} / \mathrm{MW}_{\mathrm{dc}}$ included in the plant equipment and a cable length (trays) of $1700 \mathrm{LF} /$ $\mathrm{MW}_{\mathrm{ac}}\left(=518 \mathrm{~m} / \mathrm{MW}_{\mathrm{ac}}\right)$ with a total copper scrap value of about USD 100,000/MW ${ }_{\text {ac }}$ [88]. The copper content seems to be set very high since according to the Ecoinvent database, the copper content in silicon PV modules is stated with $0.113 \mathrm{~kg} / \mathrm{m}^{2}$ [28].

The European Commission investigated the WEEE management practices in the EU28. There are few countries which already have particular statistics and recycling fees for PV modules. Currently, PV modules are included in the category 'large equipment' of the WEEE Directive ([21]; Annex IV). In 2014, the Netherlands had a WEEE collection rate of $44 \%$ excl. solar panels and $45 \%$ incl. solar panels based on the relations of put-onthe-market and waste-collection data. In 2016, the Czech Republic regulated a minimum producer fee for EoL management for solar panels of $8.50 \mathrm{CZK} / \mathrm{kg} \quad(=0.34$ EUR/kg). That is EUR 6.12 per module with a mass of $18 \mathrm{~kg}[89]$.

\section{Recycling versus re-use/export of photovoltaic modules}

The WEEE Directive [10] aims to avoid unwanted shipments of non-functional electrical and electronic equipment to developing countries according to the Basel convention [90] and the European Regulation on waste disposal [91], respectively. Annex I of the Basel Convention includes waste having as constituents, e.g. compounds of copper, zinc, arsenic, selenium, cadmium, tellurium and lead. Annex VIII explicitly includes waste electrical and electronic assemblies or scrap (No. A1180) which is contaminated with substances mentioned above. However, A1180 excludes scrap assemblies from electric power generation. In contrast to Annex VIII, Annex IX excludes waste electrical and electronic assemblies (No. B1110), e.g. under the condition that hazardous materials are included only in low concentration not causing them to exhibit an Annex III characteristic such as harmful, toxic or ecotoxic (see also EU Directive on hazardous waste [92]).

The study of Wade et al. investigated the economics of potential re-use, recycling and disposal scenarios of EoL PV modules. The study concludes that the re-use, and therefore the export out of Europe, is unlikely since future PV modules are expected to be relatively inexpensive and of higher efficiency. It is expected that the commercial scrap value of high-value recycling will exceed the decommissioning and transportation costs [88].

The potential environmental impact of hazardous substances in PV modules in the cases of recycling or replacement for re-use inside or outside of Europe can be mitigated by implementing ecodesign requirements and green public procurement criteria, which are currently under development. The requirements include the repairability of the module in the case of replacement of the bypass diodes in the junction box and the possibility to replace the whole junction box of the module. Concerning the recycling process, manufacturers should provide information regarding the possibility to separate and recover the semiconductor layer from the frame, glass, encapsulants and backsheet. On the material level, manufacturers have to declare the content in grammes of antimony, cadmium, gallium, indium, lead, silicon metal, silver and tellurium and the type of polymers including fluorinated additives of the encapsulant and backsheet of the module. Concerning inverters, the manufacturers should declare the content in grammes of lead, cadmium, silicon carbide, silver, indium, gallium and tantalum. Ecolabel criteria for residential PV systems include the restriction of lead, cadmium, flame retardants and phthalates according to the RoHS directive [31] and SVHCs according to the Material Declaration Standard IEC 62474 [93], respectively. Glass has not to include additives such as antimony and arsenic $>50$ ppm [36].

\section{Conclusions}

The study investigates the spatial distribution of freefield photovoltaic plants in Europe by Google mapping and compares the ratio of installed power of free-field to roof-top PV systems for a local case. The question of land use and land competition is discussed for different assessment methods for land transformation and land 
occupation. Likewise, a comprehensive literature review addresses key issues of hazardous constituents and their leakage in the case of module breakage, as well as endof-life issues ranging from requirements for PV module waste treatment to financial issues concerning decommissioning of end-of-life PV systems and to module recycling technologies and module re-use.

Our investigation shows that there are approximately 17,000 free-field PV plants on the commercial, industrial and utility scale installed all over Europe reflecting trends in the available national statistical data. At the end of 2017, the cumulative installed PV power in the EU28 was $115 \mathrm{GW}_{\mathrm{p}}$. The construction boom of PV plants had its peak in 2011. In countries with a large number of free-field plants, it is not clear to what extent roof-top plants account for energy production. A case study inventory of a Central European region shows a small share of about $5 \%$ based on mainly residential and few commercial scale roof-top PV plants. A survey of satellite images showed that Italy has a relatively high level of installed PV plants on large flat roofs, but their share in total energy production could not be estimated. However, the literature review and satellite image survey give the impression that the potential energy production share of roof-top systems is overestimated and that a significant increase of PV energy could only be achieved with a continuing rapid expansion of larger free-field systems.

It is recommended to conduct a broader scientific debate on land sealing and land competition as well as more detailed analyses of the land occupation of energy systems in different regions. Currently, free-field PV plants are predominantly installed in lowlands and on arable land and forest areas according to the satellite images and topographic maps. In some regions, the density of PV plants appears to be very high. The common calculation method based on one-time land transformation is insufficient to reflect the annual land competition for infrastructure and settlements, food and feed production, energy production, chemical and textile raw materials and the preservation of natural habitats. Furthermore, to properly compare the land use of energy systems, secondary effects have to be considered such as recovery time of the transformed land into the original state and impacts on the water balance in the case of fossil energy sources on the one hand and land damages by extracting lithium for storage batteries for volatile renewable energy sources, on the other. These questions call for trans-regional and global spatial energy planning.

Most PV modules contain a small but non-negligible amount of hazardous substances. They are unlikely to affect the environment during normal operation of the system, since the substances are chemically bound and encapsulated against environmental influences. Literature provides average data concerning the type and amount of hazardous substances in PV modules, and there are PV technologies available that operate without hazardous substances. However, detailed material composition data of specific module technologies and their spatial distribution are not available, especially as technologies changed continually over the years. A mandatory and publicly accessible declaration of the material composition of PV modules would be necessary for a more complete environmental life cycle assessment.

In the case of end-of-life module breakage, the lamination and protective encapsulation is destroyed, and hazardous constituents could be leached into the environment. There seems to be an emerging consensus in the literature that the leaching behaviour of metals from PV module pieces of various sizes is inadequately described in the current waste characterisation protocols that typically last 1 day. Measurements over weeks and months reveal significant losses of lead from c-Si modules and cadmium from CdTe modules in the range of tens of mass percent, but only if the leaching solution is acidic with $\mathrm{pH}$ values of $3-5$; neutral $\mathrm{pH}$ appears to cause little leaching of these metals. Results of subsequent fate and toxicity modelling are less conclusivethey vary with the element and the module technology studied and also with the assumed scenarios (dilution and $\mathrm{pH}$ of leaching solvent). Only one study was found that sampled the soil underneath an operating PV plant that had begun operations 5 years earlier, with results that underline the need for more research into measured impacts of real PV plants in the field.

The end-of-life management of photovoltaic systems will face major challenges when the first large scale free-field plants reach the end of their lifetime in about 15 years. Even though the waste treatment requirements and financing of PV module recycling and disposal in the European Union is regulated by the WEEE Directive, some major legal, financial and technological questions are still open. One key issue is the classification of PV modules as hazardous or non-hazardous waste, since there is a small amount of hazardous substances included dependent on the module technology. The classification depends on the country-specific limit values for hazardous substances and the leakage behaviour of the respective toxic metals.

The second key issue is the financing of the decommissioning of PV plants, which is not covered by the WEEE Directive. In the literature, there are several positive and negative scenarios about costs and proceeds of decommissioning and recycling, particularly for large scale PV plants. The aim is to finance the entire waste treatment from the proceeds of the recycled raw materials and the mandatory producer fees. The valuable materials are steel, copper, silver and aluminium. However, the content and salvage value of copper seems to be 
overestimated. In the case of silicon-based PV modules, there are major research efforts to produce profitable secondary silicon with a lower carbon footprint than virgin silicon material but with a comparable purity. Other scenarios include the re-use and export of PV modules which is theoretically legal, since assemblies from electric power generations are not covered by the Basel Convention. In any case, it must be ensured that inoperable free-field PV plants of all scales do not remain on-site for decades due to a lack of financial means for decommissioning.

\section{Supplementary information}

Supplementary information accompanies this paper at https://doi.org/10 1186/s13705-020-00263-4.

Additional file 1: Figure A1. Free-field PV plants in Central Europe (yellow markers installed until 2014/15, orange markers since 2015). The blackened areas are not representative. (Own work; QGIS Map: OpenTopoMap [24]).

Additional file 2: Figure A2. Free-field PV plants in Spain (yellow markers installed until 2014/15, orange markers since 2015). (Own work; QGIS Map: OpenTopoMap [24]).

Additional file 3: Figure A3. Free-field PV plants in Italy (yellow markers installed until 2014/15, orange markers since 2015). (Own work: QGIS Map: OpenTopoMap [24]).

Additional file 4: Figure A4. Free-field PV plants in Greece (yellow markers installed until 2014/15, orange markers since 2015). (Own work; QGIS Map: OpenTopoMap [24]).

Additional file 5: Figure A5. Free-field PV plants in the United Kingdom (yellow markers installed until 2014/15, orange markers since 2015). The blackened areas are not representative. (Own work; QGIS Map: OpenTopoMap [24]).

\section{Abbreviations}

a-Si: Amorphous silicon (PV module technology); ac: Alternating current; AT: Austria; BE: Belgium; BG: Bulgaria; c-Si: Crystalline silicon (PV module technology, includes either polycrystalline Si modules or monocrystalline Si modules); cap: Capita; CdSe: Cadmium selenide (PV module technology); CdTe: Cadmium telluride (PV module technology); cf.: Confer (compare with); CIGS: Copper indium gallium diselenide (PV module technology); CIS: Copper indium diselenide (PV module technology); CY: Cyprus; CZ: Czech Republic; CZTS: Copper zinc tin sulphide; DC: Direct current; DE: Germany; DK: Denmark; e-waste: Electrical and electronic waste; EE: Estonia; EEE: Electrical and electronic equipment; EoL: End-of-life; ES: Spain; EU: European Union; EU28: 28 member states of the European Union as of 2013 (incl. Croatia of. EU27); EUR: Euro; FI: Finland; FR: France; GR: Greece; GWp: Gigawatt peak; HR: Croatia; HU: Hungary; IE: Ireland; IT: Italy; LCl: Life cycle inventory; LF: Linear foot; LT: Lithuania; LU: Luxembourg; LV: Latvia; max.: Maximum; mc-Si: Multicrystalline (or polycrystalline) silicon (PV module technology); MT: Malta; MWp: Megawatt peak; MWth: Megawatt thermal; NL: The Netherlands; NUTS: Nomenclature des unités territoriales statistiques (European Union); OPV: Organic photovoltaic (PV module technology); $\mathrm{Pb}$ : Lead; $\mathrm{pH}$ : Scale used to specify how acidic or basic a water-based solution is; pH 3: Acidic solutions; pH7: Neither acidic nor basic solution; pH 11: Basic solutions; PL: Poland; ppm: Parts per million; PSC: Perovskite solar cells (PV module technology); PT: Portugal; PV: Photovoltaic; QDSC: Quantum-dot solar cells (PV module technology); RO: Romania; SE: Sweden; Si: Silicon (PV module technology); SI: Slovenia; SK: Slovakia; SVHC: Substance of very high concern; UK: United Kingdom; USD: US dollar; w/w: Weight/weight; WEEE: Waste electrical and electronic equipment

\section{Acknowledgements}

The authors acknowledge the TU Wien Bibliothek for financial support through its Open Access Funding Program. In particular, the authors thank
Michael Narodoslawsky for contributing his expertise through insightful discussions and valuable inputs and for proofreading the manuscript.

\section{Authors' contributions}

MF designed the present study, collected and analysed the geospatial data, analysed the literature and wrote the main part of the manuscript. GP reviewed and wrote the review of PV metals leaching behaviour and contributed to the section on the end-of-life management of PV modules. All authors read and approved the final manuscript.

\section{Authors' information}

MF is a Research Assistant at the Institute of Sensor and Actuator Systems at the TU Wien. She holds a Master in Electrical Engineering/Power Technology and a PhD in Process Engineering from the TU Wien. Her research interests focus on the environmental assessment of new electrical and electronic appliances and energy supply systems.

GP is an Academic Instructor at the University of Applied Sciences Burgenland, Austria. He holds a Master in Engineering Physics from TU Wien and a PhD in Environmental Engineering from Tulane University. His research interests focus on the method of life cycle assessment and its applications to energy systems.

\section{Funding}

Not applicable

\section{Availability of data and materials}

Detailed geographical data of the mapped photovoltaic plants are not available as datasets, but they are verifiable at any time in Google Earth. All other literature and data generated and/or analysed during this study are included in this published article and/or provided as open data according to the references.

Ethics approval and consent to participate

Not applicable

Consent for publication

Not applicable

Competing interests

The author declares that they have no competing interests.

\section{Author details}

${ }^{1}$ TU-Wien, Gußhausstraße 27-29/E366, 1040 Wien, Austria. ${ }^{2}$ University of Applied Sciences Burgenland, Steinamangerstrasse 21, 7423, Pinkafeld, Austria.

Received: 17 August 2019 Accepted: 3 August 2020

Published online: 31 August 2020

References

1. European Commision (2009) Directive 2009/28/EC of the European Parliament and of the Council on the promotion of the use of energy from renewable sources.

2. DIRECTIVE (EU) $2018 / 2001$ OF THE EUROPEAN PARLIAMENT AND OF THE COUNCIL of 11 December 2018 on the promotion of the use of energy from renewable sources (recast).

3. Dumke H (2017) Erneuerbare Energien für Regionen - Flächenbedarfe und Flächenkonkurrenzen. Dissertation. Technische Universität, Wien

4. Franz M, Narodoslawsky M (2020) Carbon Footprint, Sustainable Process Index und Flächenverbrauch von PV-Anlagen und anderen erneuerbaren/ fossilen Energieerzeugungssystemen. 16. Symposium Energieinnovation, 12. 14.02.2020, Graz/Austria, 14 pages. https://www.tugraz.at/events/eninnov202 0/nachlese/download-beitraege/stream-b/\#c279316 [03/2020].

5. Fthenakis V, Kim HC (2009) Land use and electricity generation: a life-cycle analysis. Renew Sust Energ Rev 13(2009):1465-1474

6. EurObserv'ER (2018) Photovoltaic barometer 2010-2018. http://www. eurobserv-er.org [02/2019].

7. Fraunhofer ISE (2019) Photovoltaics report, updated: 14 March 2019. https:// www.ise. fraunhofer.de/de/veroeffentlichungen/studien/photovoltaicsreport.html [03/2019]. 
8. Solar Power Europe (2015) Global market outlook for solar power / 20152019.

9. Solar Power Europe (2019) Global market outlook for solar power / 20192023.

10. European Commision (2012) Directive 2012/19/EU of the European Parliament and of the Council of 4 July 2012 on waste electrical and electronic equipment (WEEE) (recast).

11. Baldé CP, Forti V, Gray V, Kuehr R, Stegmann P (2017) The Global E-waste Monitor-2017. United Nations University (UNU), International Telecommunication Union (ITU) \& International Solid Waste Association (ISWA), Bonn/Geneva/Vienna

12. Monier V, Hestin M (2011) Study on photovoltaic panels supplementing the impact assessment for a recast of the WEEE Directive. Final report 14 April 2011. Bio Intelligence Service, France

13. Google Earth (2019) https://www.google.com/earth/ [12/2019].

14. ENFO-Energie GmbH (2019) Solarpark Neuhardenberg. Größter Solarpark Europas - ein Projekt der ENFO, Frankfurt / Oder, Germany. https://www. enfo-energie.biz/ [04/2019].

15. ISO 14040 (2006) Environmental management — life cycle assessment — principles and framework.

16. ISO 14044 (2006) Environmental management — life cycle assessment requirements and guidelines.

17. Eurostat (2019) https://ec.europa.eu/eurostat/ [04/2019].

18. ITOworld (2014) http://www.toworld.com/; Maps: Electricity generation [05/2014].

19. Energy Register (2014) http://www.en.energyregister.gr/; Map; [05/2014].

20. JRC-Joint Research Centre (2014) Photovoltaic Geographical Information System (PVGIS). http://re.jrc.ec.europa.eu/pvgis/ [05/2014].

21. European Commision (2018) Regulation (EC) No 1059/2003 of the European Parliament and of the Council of 26 May 2003 on the establishment of a common classification of territorial units for statistics (NUTS) Consolidated version 18.01.2018

22. Franz M, Szendiuch I (2014) Distribution of free-field photovoltaic plants in Europe and exemplarily in South Moravia, Czech Republic. Proceedings of the IEEE 2014 37th International Spring Seminar on Electronics Technology, Dresden, 2014, pp. 350-354. IEEE Xplore.

23. Franz M (2019) Environmental assessment of new electrical and electronic appliances and energy supply systems. Dissertation TU, Wien

24. QGIS (2020) A free and open source geographic information system https:// www.qgis.org/ [02/2020]

25. JUFA s.r.o. (2017) The fourth largest solar power plant in the Czech Republic has a new owner: Czech investment group Jufa. Press release from investment group Jufa, 7 November 2017. https://www.jufa.cz/ [07/2019].

26. Czech Statistical Office (2019) Population of municipalities. 1 January 2019, Praha, 2019.

27. EurObserv'ER (2014) Solar thermal and concentrated solar power barometer - EurObserv'ER, May 2014.

28. Ecoinvent (2020) Ecoinvent database. https:/www.ecoinvent.org/ [02/2020).

29. Koellner T, De Baan L, Beck T, Brandão M, Civit B, Goedkoop M, Margni M, Milà i Canals L, Müller-Wenk R, Weidema B, Wittstock B (2013) Principles for life cycle inventories of land use on a global scale. Int J Life Cycle Assess 18: 1203-1215. https://doi.org/10.1007/s11367-012-0392-0

30. European Commission (2019) Product Environmental Footprint Category Rules (PEFCR). Photovoltaic modules used in photovoltaic power systems for electricity generation. Version: 1.1. Date of publication: 12 February 2019. Time validity: 31st December 2020. https:/ec.europa.eu/ environment/eussd/smgp/pdf/PEFCR_PV_electricity_v1.1.pdf [02/2020].

31. Directive 2011/65/EU of the European Parliament and of the Council of 8 June 2011 on the restriction of the use of certain hazardous substances in electrical and electronic equipment (recast).

32. Regulation (EC) No 1907/2006 of the European Parliament and of the Council of 18 December 2006 concerning the Registration, Evaluation, Authorisation and Restriction of Chemicals (REACH), establishing a European Chemicals Agency, amending Directive 1999/45/EC and repealing Council Regulation (EEC) No 793/93 and Commission Regulation (EC) No 1488/94 as well as Council Directive 76/769/EEC and Commission Directives 91/155/EEC, 93/67/EEC, 93/105/EC and 2000/21/EC

33. Regulation (EC) No 1272/2008 of the European Parliament and of the Council of 16 December 2008 on classification, labelling and packaging of substances and mixtures, amending and repealing Directives 67/548/EEC and 1999/45/EC, and amending Regulation (EC) No 1907/2006.
34. European Chemicals Agency-ECHA (2020) Candidate List of substances of very high concern for Authorisation. https://echa.europa.eu/candidate-listtable $[02 / 2020]$

35. Fiducia TAM, Mendis BG, Li K et al (2019) Understanding the role of selenium in defect passivation for highly efficient selenium-alloyed cadmium telluride solar cells. Nat Energy 4:504-511. https://doi.org/10.1038/ s41560-019-0389-z

36. Dodd N, Espinosa N (2019) Preparatory study for solar photovoltaic modules, inverters and systems. (Draft) Task 8 Report: Policy recommendations. European Commission, Joint Research Centre, December 2019.

37. Landesanstalt für Umwelt Baden-Württemberg (2020) REACH Cadmiumnitrat. https://www.reach.baden-wuerttemberg.de/-/cadmiumnitrat (status of complete: 11th Dec. 2019) [02/2020].

38. Diermann R (2011) Blei bleibt beliebt. Photovoltaik - Solartechnik für Installateure, Planer, Architekten. Ausgabe 04-2011. [German]

39. Bayerisches Landesamt für Umwelt (2011) Berechnung von Immissionen beim Brand einer Photovoltaik-Anlage aus Cadmiumtellurid-Modulen. Augsburg, 2011. [German]

40. Nover J, Huber S, Zapf-Gottwick R, Werner JH, Feifel C, Koch M, Metzger JW (2017) Schadstofffreisetzung aus Photovoltaik-Modulen, Abschlussbericht. Universtät Stuttgart. Gefördert durch das Bundesministerium für Wirtschaft und Energie, Förderkennzeichen: 0325718. 138 pages. [German]

41. Sinha P, Balas R, Krueger L, Wade A (2012) Fate and transport evaluation of potential leaching risks from cadmium telluride photovoltaics. Environ Toxicol Chem 31(7):1670-1675. https://doi.org/10.1002/etc.1865

42. Jungbluth N, Stucki M, Frischknecht R (2009) Photovoltaics. In: Dones R et al (eds) Sachbilanzen von Energiesystemen: Grundlagen für den ökologischen Vergleich von Energiesystemen und den Einbezug von Energiesystemen in Ökobilanzen für die Schweiz. ecoinvent report No. 6-XII. Swiss Centre for Life Cycle Inventories, Dübendorf

43. Nain P, Kumar A (2020) Initial metal contents and leaching rate constants of metals leached from end-of-life solar photovoltaic waste: an integrative literature review and analysis. Renew Sust Energ Rev 119:109592

44. Köntges M, Kurtz S, Packard C, Jahn U, Berger KA, Kato K, Friesen T, Liu H, Van Iseghem M et al. (2014) Review of failures of photovoltaic modules. Report IEA-PVPS T13-01:2014.

45. Steinberger $H$ (1998) Health, safety and environmental risks from the operation of CdTe and CIS thin-film modules. Progress in Photovoltaics: Research and Applications 6, no. 2 (March 1998): 99-103.

46. Collins MK, Anctil A Implications for current regulatory waste toxicity characterisation methods from analysing metal and metalloid leaching from photovoltaic modules. Int J Sust Energy 36(2017, 6):531-544

47. Zeng C, Ramos-Ruiz A, Field JA, Sierra-Alvarez R (2015) Cadmium telluride (CdTe) and cadmium selenide (CdSe) leaching behavior and surface chemistry in response to PH and O2. J Environ Manag 154(May 2015):78-85

48. Steinberger H (1995) Umwelt- und Gesundheitsauswirkungen der Herstellung und Anwendung sowie Entsorgung von Dünnschichtsolarzellen und Modulen. Bundesministerium für Forschung und Technologie, Forschungsvorhaben 0329205 A, Kenntnisstandbericht; Fraunhoferinstitut für Festkörpertechnologie München, 1995, 36 pages. (German)

49. Okkenhaug G (2010) Environmental risks regarding the use and final disposal of CdTe PV modules. Norwegian Geotechnical Institute (NGI) report no 20092155-00-5-R, 16 April 2010.

50. Zimmermann YS, Schäffer A, Corvini PFX, Lenz M (2013) Thin-film photovoltaic cells: long-term metal(loid) leaching at their end-of-life. Environ Sci Technol 2013(47):13151-13159

51. Sinha P, Wade A (2015) Assessment of leaching tests for evaluating potential environmental impacts of PV module field breakage. IEEE J Photovoltaics 2015:1-5

52. Sinha P (2015) Cadmium telluride leaching behavior: discussion of Zeng et al. (2015). J Environ Manag 163(November 2015):184-185

53. Nover J, Zapf-Gottwick R, Feifel C (2017) Long-term leaching of photovoltaic modules. Jpn J Appl Phys 56:08MD02-1-08MD02-6. https://doi. org/10.7567/JJAP.56.08MD02

54. Sinha P, Wade A (2018) Comment on "Long-term leaching of photovoltaic modules". Jpn J Appl Phys 57:019101

55. Nover J (2018) Reply to "Comment on 'Long-term leaching of photovoltaic modules' ". Jpn J Appl Phys 57:019102

56. Zapf-Gottwick R, Koch M, Fischer K, Schwerdt F, Hamann L, Kranert M, Metzger JW, Werner JH (2015) Leaching hazardous substances out of photovoltaic modules. Int J Adv Appl Phys Res 2015(2):7-14 
57. Celik I, Song Z, Phillips AB, Heben MJ, Apul D (2018) Life cycle analysis of metals in emerging photovoltaic (PV) technologies: a modeling approach to estimate use phase leaching. J Clean Prod 186(2018):632-639

58. Robinson SA, Meindl GA (2019) Potential for leaching of heavy metals and metalloids from crystalline silicon photovoltaic systems. J Nat Res Dev 09:19-24

59. Directive 2008/98/EC of the European Parliament and of the Council of 19 November 2008 on waste and repealing certain Directives.

60. DIN EN 50419 on the marking of electrical and electronic equipment.

61. DIN EN 50574 on the collection, logistics \& treatment requirements for endof-life household appliances containing volatile fluorocarbons or volatile hydrocarbons

62. TS 50574-2: Collection, logistics \& treatment requirements for end-of-life household appliances containing volatile fluorocarbons or volatile hydrocarbons - Part 2: specification for de-pollution.

63. DIN EN 50625-1 (VDE 0042-13-1) (2014) Collection, logistics \& treatment requirements for WEEE - Part 1: General treatment requirements.

64. TS 50625-3-2: Collection, logistics \& treatment requirements for WEEE - Part 3-2: Specification for de-pollution - Lamps.

65. DIN EN 50625-2-2: Collection, logistics \& treatment requirements for WEEE - Part 2-2: Treatment requirements for WEEE containing CRTs and flat panel displays.

66. TS 50625-3-3: Collection, logistics \& treatment requirements for WEEE - Part 33: Specification for de-pollution- WEEE containing CRTs and flat panel displays.

67. DIN EN 50625-2-3: Collection, logistics \& treatment requirements for WEEE Part 2-3: Treatment requirements for temperature exchange equipment.

68. TS 50625-3-4: Collection, logistics \& treatment requirements for WEEE - Part 3-4: Specification for de-pollution-temperature exchange equipment.

69. DIN EN 50625-2-4: Collection, logistics \& treatment requirements for WEEE Part 2-4: Treatment requirements for photovoltaic panels.

70. DIN CLC/TS 50625-3-5: Collection, logistics \& treatment requirements for WEEE - Part 3-5: Specification for de-pollution-photovoltaic panels.

71. TS 50625-4: Collection, logistics \& treatment requirements for WEEE - Part 4: Specification for the collection and logistics associated with WEEE.

72. TS 50625-5: Collection, logistics \& treatment requirements for WEEE - Part 5: Specification for the end-processing of WEEE fractions - copper and precious metals

73. DIN EN 50614: Requirements for the preparing for re-use of waste electrical and electronic equipment (not yet published).

74. In't Groen B, Stengs L, Zonneveld M (2017) European Standards for Waste Electrical and Electronic Equipment(WEEE). CENELEC Publication 2017. https://www.cencenelec.eu/news/publications/publications/weee-brochure. pdf [10/2019].

75. PHOTON International GmbH (2019) PHOTON Databases, https://www. photon.info/en/photon-databases [12/2019]

76. Thomas R, Pelletier D, Hoffmann MC, Rakotoniaina JP, Federzoni L (2017) Cabriss: Market analysis and business models for a circular economy in PV. EU PVSEC 2017, Amsterdam

77. Brenner W, Adamovic N (2017) A circular economy for photovoltaic waste the vision of the European Project CABRISS. Proceedings of the MIPRO 2017, Opatija, pp 146-151

78. CABRISS Deliverable Report D7.7 (2017) Public business plan. CABRISSImplementation of a circular economy based on recycled, reused and recovered indium, silicon and silver materials for photovoltaic and other applications. Horizon 2020, EU Grant agreement ID: 641972, 2015-2018.

79. IEA-International Energy Agency (2018) End-of-life management of photovoltaic panels: trends in PV module recycling technologies. Report IEA-PVPS T12-10:2018.

80. Mahmoudi S, Huda N, Alavi Z, Islam MT, Behnia M (2019) End-of-life photovoltaic modules: a systematic quantitative literature review. Resour Conserv Recycl 146(2019):1-16

81. Salim HK, Stewart RA, Sahin O, Dudley M (2019) Drivers, barriers and enablers to end-of-life management of solar photovoltaic and battery energy storage systems: a systematic literature review. J Clean Prod 211(2019):537-554

82. PV CYCLE (2019) http://www.pvcycle.org/ [10/2019].

83. UHF (2019) Tarife Haushalt/Gewerbe. https://ufh.at/leistungen/entsorgungund-entpflichtung/tarife/ [10/2019].

84. Sinha P, Wade A (2018) Addressing hotspots in the product environmental footprint of CdTe photovoltaics. IEEE J Photovoltaics 8(3):793-797

85. Vargas C, Chesney M (2020) End of life decommissioning and recycling of solar panels in the United States. A real options analysis. J Sust Finance Invest. https://doi.org/10.1080/20430795.2019.1700723
86. NYSERDA (2019) New York Solar Guidebook for local governments. NYSE RDA, Albany

87. Raimi D (2017) Decommissioning US power plants. Decisions, costs, and key issues. Resources for the Future (RFF) Report, October 2017.

88. Wade A, Sinha P, Drozdiak K, Brutsch E (2017) Beyond waste - the fate of end-of-life photovoltaic panels from large scale PV installations in the EU. The socio-economic benefits of high value recycling compared to re-use. Proceedings of the 33rd European Photovoltaic Solar Energy Conference and Exhibition, ISBN 3-936338-47-7, pp. 1507 - 1514. DOl: https://doi.org/10. 4229/EUPVSEC20172017-5EO.1.1.

89. Kling M, Zotz F, Huranova D (2017) WEEE compliance promotion exercise. Final report. Reference: 07.0201/2016/737282/ETI/ENV B.3. EUROPEAN COMMISSION Directorate-General for Environment. Report prepared by Bipro and Deloitte.

90. United Nations Environment Programme (1989/2018) Basel convention on the control of transboundary movements of hazardous wastes and their disposal. Protocol on liability and compensation for damage resulting from transboundary movements of hazardous wastes and their disposal. Published by the Secretariat of the Basel Convention (SBC) in May 2018.

91. Regulation (EC) No 1013/2006 of the European Parliament and of the Council of 14 June 2006 on shipments of waste.

92. Council Directive of 12 December 1991 on hazardous waste (91/689/EEC) European Union.

93. IEC 62474 (2019) Material declaration for products of and for the electrotechnical industry.

\section{Publisher's Note}

Springer Nature remains neutral with regard to jurisdictional claims in published maps and institutional affiliations.
Ready to submit your research? Choose BMC and benefit from:

- fast, convenient online submission

- thorough peer review by experienced researchers in your field

- rapid publication on acceptance

- support for research data, including large and complex data types

- gold Open Access which fosters wider collaboration and increased citations

- maximum visibility for your research: over $100 \mathrm{M}$ website views per year

At BMC, research is always in progress.

Learn more biomedcentral.com/submissions 